\title{
P2X3 purinergic receptor overexpression is associated with poor recurrence-free survival in hepatocellular carcinoma patients
}

\author{
Janielle P. Maynard ${ }^{1,2}$, Ju-Seog Lee ${ }^{3}$, Bo Hwa Sohn ${ }^{3}$, Xiaoying Yu${ }^{4}$, Dolores Lopez- \\ Terrada ${ }^{5}$, Milton J. Finegold ${ }^{2,5}$, John A. Goss ${ }^{2,6}$ and Sundararajah Thevananther ${ }^{1,2}$ \\ ${ }^{1}$ Department of Pediatrics, Division of Gastroenterology, Hepatology and Nutrition, Texas Children's Liver Center, Houston, \\ TX, USA \\ 2 Program in Translational Biology and Molecular Medicine, Baylor College of Medicine, Houston, TX, USA \\ 3 Department of Systems Biology, UT MD Anderson Cancer Center, Houston, TX, USA \\ ${ }^{4}$ Department of Medicine, Division of Gastroenterology, Baylor College of Medicine, Houston, TX, USA \\ ${ }^{5}$ Department of Pathology and Immunology, Baylor College of Medicine, Houston, TX, USA \\ ${ }^{6}$ Department of Surgery, Baylor College of Medicine, Houston, TX, USA \\ Correspondence to: Sundararajah Thevananther, email: sundarat@bcm.edu \\ Keywords: hepatocellular carcinoma, cell-cycle, extracellular ATP, purinergic receptors, JNK signaling \\ Received: June 02, $2015 \quad$ Accepted: September 17, $2015 \quad$ Published: October 26, 2015
}

This is an open-access article distributed under the terms of the Creative Commons Attribution License, which permits unrestricted use, distribution, and reproduction in any medium, provided the original author and source are credited.

\section{ABSTRACT}

P2 purinergic receptors are overexpressed in certain cancer tissues, but the pathophysiologic relevance of purinergic signaling in hepatocellular carcinoma (HCC) remains unknown. To examine the role of $\mathrm{P} 2$ purinergic signaling in the pathogenesis of HCC and characterize extracellular nucleotide effects on HCC cell proliferation, two independent HCC patient cohorts were analyzed for $\mathbf{P} 2$ purinergic receptor expression, and nucleotide treated HCC cell lines were evaluated for effects on proliferation and cell cycle progression. Our studies suggest that multiple P2 purinergic receptor isoforms are overexpressed in liver tumors, as compared to uninvolved liver, and dysregulation of $\mathbf{P 2}$ purinergic receptor expression is apparent in HCC cell lines, as compared to human primary hepatocytes. High P2X3 purinergic receptor expression is associated with poor recurrence-free survival (RFS), while high P2Y13 expression is associated with improved RFS. Extracellular nucleotide treatment alone is sufficient to induce cell cycle progression, via activation of JNK signaling, and extracellular ATPmediated activation of $\mathbf{P} 2 X 3$ receptors promotes proliferation in HCC cells. Conclusion: Our analysis of HCC patient livers and HCC cells in vitro identifies a novel role for dysregulation of $\mathbf{P 2}$ purinergic signaling in the induction of hyper-proliferative HCC phenotype and identifies $\mathrm{P} 2 \mathrm{X} 3$ purinergic receptors as potential new targets for therapy.

\section{INTRODUCTION}

Hepatocellular carcinoma (HCC) is the second leading cause of cancer deaths worldwide [1]. The incidence and deaths resulting from HCC have steadily increased in the US over the past three decades, and it is predicted that they will continue to rise [2]. Currently, the prognosis for HCC is dismal with overall survival rates of $3-7 \%[3,4]$. Treatment options for HCC are limited, with liver resection or orthotopic liver transplantation (OLT) as the best approaches. Resection has a very high recurrence rate of up to $70 \%$ at 5 years. OLT has a better prognosis, however most patients are not suitable candidates and a scarcity of organs contribute to longer wait times; more than 16,000 patients were on the wait list for livers in $2012[5,6]$. Over $75 \%$ of HCC are caused by viral infections such as Hepatitis C Virus (HCV) and 70-90\% of all tumor development is associated with chronic liver injury, inflammation and cirrhosis [3].

It is well established that liver injury with cellular stress and inflammation is a potent trigger for ATP release from hepatocytes and other liver cells [7-9]. 
Table 1: Purinergic receptor expression in HCC patients in the TMC Cohort.

\begin{tabular}{|c|c|c|}
\hline \multirow{2}{*}{ Receptor Subtype } & $\begin{array}{c}\text { High } \\
\text { Expression (\%) }\end{array}$ & $\begin{array}{c}\text { High } \\
\text { Expression (\%) }\end{array}$ \\
\cline { 2 - 3 } & (vs uninvolved) & 79 \\
\hline P2X3 & 60 & 67 \\
\hline P2Y14 & 48 & 40 \\
\hline P2Y2 & 43 & 79 \\
\hline P2Y6 & 43 & 52 \\
\hline P2X6 & 40 & 77 \\
\hline P2Y4 & 40 & 52 \\
\hline P2X1 & 36 & 83 \\
\hline P2X2 & 36 & 38 \\
\hline P2X4 & 36 & 60 \\
\hline P2X5 & 36 & 67 \\
\hline P2X7 & 33 & 43 \\
\hline P2Y1 & 33 & 55 \\
\hline P2Y11 & 33 & 43 \\
\hline P2Y12 & 33 & 40 \\
\hline P2Y13 & 31 & 5 \\
\hline
\end{tabular}

Frequency (\%) of HCC patients with high mRNA expression of P2 Purinergic receptor subtypes as compared the uninvolved liver or normal liver.

Extracellular ATP via the activation of cell surface P2 purinergic receptors influences cell proliferation, differentiation and apoptosis [10]. We have previously shown that extracellular ATP-mediated P2 purinergic receptor activation promotes cell-cycle progression and proliferation in rat primary hepatocytes via c-Jun N-terminal Kinase (JNK) pathway in vitro and hepatocyte proliferation in response to $70 \%$ partial hepatectomy in vivo $[11,12]$. Extracellular ATP-mediated activation of P2X (ligand gated ion channels) and P2Y (G proteincoupled) receptors have been reported to influence cell proliferation, migration or apoptosis of various cancer cell types [10, 13-16]. Studies suggest that extracellular ATP-mediated activation of $\mathrm{P} 2 \mathrm{Y} 2$ receptor promotes proliferation and migration in HCC cells[17]; however the role of the remaining $14 \mathrm{P} 2$ receptor isoforms in $\mathrm{HCC}$ is currently unknown. ATP levels in the tumor interstitium of mice was measured in the hundreds micro molar range compared to near undetectable levels in healthy tissues [18].

Ectonucleotidases such as CD39 decrease extracellular nucleotide concentrations by hydrolyzing nucleotides to nucleosides and ultimately adenosine $[19,20]$. Deletion of $C d 39$ in mice is shown to increase hepatocyte proliferation and promote hepatocarcinogenesis [20]. Furthermore, P2Y2 mRNA and protein expression are increased in human HCC cells compared to normal hepatocytes and others have shown that there is increased P2Y2 and P2Y4 receptor expression in other cancers [17, $21,22]$. Recently, peritumoral $\mathrm{P} 2 \mathrm{X} 7$ purinergic receptor expression has been associated with poor survival in HCC patients after surgical resection[23]. However, P2 purinergic receptor expression and its role in hepatocyte cell cycle progression in human HCC remain unexplored.

The purpose of this study was to examine the role of P2 purinergic signaling in the pathogenesis of HCC in patients and characterize the influence of extracellular nucleotides on HCC cell proliferation. Our analysis reveals dysregulation of $\mathrm{P} 2$ purinergic receptor expression in HCC tumors, as compared to the uninvolved area of the same patient, and compared to normal livers. Increased frequency of $\mathrm{P} 2$ purinergic receptor upregulation in patients with $\mathrm{HCV}$ versus those with non-viral etiologies identifies a unique subset of viral-induced $\mathrm{HCC}$ overexpressing P2 purinergic receptors. We show that $\mathrm{P} 2 \mathrm{X} 3$ purinergic receptor overexpression is associated with poor recurrence-free survival in patients with HCC. Our in vitro findings suggest that nucleotide treatment alone was sufficient to induce HCC cell proliferation, and provide mechanistic insights into the potential role of dysregulation of purinergic signaling in the induction of hepatocyte cell-cycle control associated with $\mathrm{HCC}$ 
pathogenesis.

\section{RESULTS}

\section{Increased P2 purinergic receptor mRNA expression in Human HCC livers}

To determine if $\mathrm{P} 2$ purinergic receptor expression is dysregulated in HCC livers, we analyzed 42 pairs of HCC livers (uninvolved $v s$. tumor) and 6 normal donor liver samples from the TMC cohort. Twenty-one patients were infected with Hepatitis C Virus (HCV), 5 patients with Hepatitis B Virus (HBV) and 10 patients with non-viral etiologies. Information on the etiology was unavailable for 6 patients (Suppl. Table 1). Relative expression of all 15 P2 purinergic receptor isoforms was analyzed by qRT-PCR. Multiple $\mathrm{P} 2$ purinergic receptor isoforms were elevated $\geq$ 2 -fold in liver tumors ('high' expression) as compared to uninvolved areas of the liver (Table 1). Our results reveal that $31 \%$ of patients in the TMC cohort exhibited 'high' expression of at least one $\mathrm{P} 2$ purinergic receptor isoform, while $60 \%$ of patients exhibited 'high' P2X3 mRNA expression in liver tumors, compared to their uninvolved areas (Figure 1A). P2X3 protein overexpression was observed in HCC tumors compared to uninvolved livers by Western blotting of total homogenates (Fig 1B). HepG2 cell total protein was used as a positive control. Further validation was done by immunohistochemical analysis of tumors, uninvolved areas of HCC patient livers, and normal liver which revealed that $\mathrm{P} 2 \mathrm{X} 3$ protein overexpression was predominant in hepatocytes (Figure 1C). P2 purinergic receptor mRNA expression was significantly elevated in HCC tumors, as compared to uninvolved areas; despite apparent dysregulation of P2 purinergic receptor expression in the uninvolved areas of most of the patient livers, as compared to normal livers (Table 1). These findings suggest that dysregulation of $\mathrm{P} 2$ purinergic receptor expression in chronic liver injury may precede HCC development.

\section{P2 purinergic receptor expression correlates with HCC patient survival}

The upregulation of multiple $\mathrm{P} 2$ purinergic receptor isoforms observed in HCC prompted us to question the significance of dysregulation of $\mathrm{P} 2$ purinergic receptor expression on HCC survival in a larger Korean cohort (188 patients). Demographic and pathologic features of this Korean cohort are presented in Suppl. Table 2. Patients were stratified according to 'high' (above median) and 'low' (below median) P2 purinergic receptor expression based on microarray gene expression analysis of resected livers. Patients with 'high' P2X3 expression had a significantly lower recurrence-free survival (RFS) rate than those patients with 'low' $\mathrm{P} 2 \mathrm{X} 3$ receptor expression $(p=0.0001)$. On the other hand, patients with high P2Y13 expression had significantly improved recurrence free survival ( $p=0.007$ ) (Figure 1D). Recall that in the TMC cohort P2X3 was observed as the receptor with the greatest frequency of 'high' expression in HCC tumor samples $(60 \%)$ and P2Y13 was identified as the receptor with the lowest frequency of 'high' expression (31\%) (Figure 1D).

Corroborating our findings, Oncomine analysis revealed that $\mathrm{P} 2 \mathrm{X} 3 \mathrm{mRNA}$ is significantly overexpressed in the Mas_Liver dataset ( $p=9.23 \mathrm{E}-7)$, while P2Y13 mRNA is underexpressed in the Chen Liver dataset $(\mathrm{p}=$ 1.03E-14) (Suppl. Figure 1) [25, 26]. It is noteworthy that P2X3 was ranked among the top 7\% overexpressed genes in the Mas_Liver dataset, which included exclusively HCV-positive HCC samples and HCV-negative normal livers. In the TMC cohort $43 \%$ of patients exhibited 'low' P2Y13 mRNA expression, which was ranked among the top $4 \%$ underexpressed genes in Chen_Liver dataset, and included HCC samples of viral and non-viral origin. Dysregulation of P2X3 and P2Y13 mRNA expression was evident in HCC livers, despite comparable DNA copy numbers of these genes between HCC and normal in the TCGA, Guichard_Liver and Guichard_Liver 2 DNA datasets $[24,29]$.

\section{P2 purinergic receptor upregulation is more frequent in $\mathrm{HCV}$ patients}

In order to gain insight into the etiology of HCC and its influence on $\mathrm{P} 2$ purinergic receptor overexpression in HCC livers, we stratified our TMC patients based on their history of viral infection and found that P2 purinergic receptor upregulation, as assessed by qRTPCR was more prevalent among those patients infected with $\mathrm{HCV}$, as compared to non-viral groups (Figure 1E). P2X3 overexpression is evident in $75 \%$ of $\mathrm{HCV}$ patients as compared to only $30 \%$ of non-viral patients. Immunohistochemical analysis of patient livers with HBV (patient \# 30), HCV (patient \# 29, 32, 36) and non viral patients (patient \# 16, 28,50) indicates that $\mathrm{P} 2 \mathrm{X} 3$ overexpression in $\mathrm{HCC}$ tumors as compared to uninvolved livers can be detected in HCC livers, irrespective of etiology (Figure 1C \& Suppl. Figure 2).

To determine whether viral infection influences recurrence free survival, Kaplan-Maier analysis was done on the Korean cohort. Patients were stratified as HBV positive or negative AND P2X3 'high' or 'low' as previously defined. Regardless of HBV status, patients with 'high' P2X3 expression had lower RFS than patients with 'low' P2X3 expression (Figure 1F). Among HBV positive patients, those with high $\mathrm{P} 2 \mathrm{X} 3$ expression had significantly lower RFS compared to those with low P2X3 expression (Suppl. Figure 3A). While there was a considerable difference in median survival between P2X3 
A.

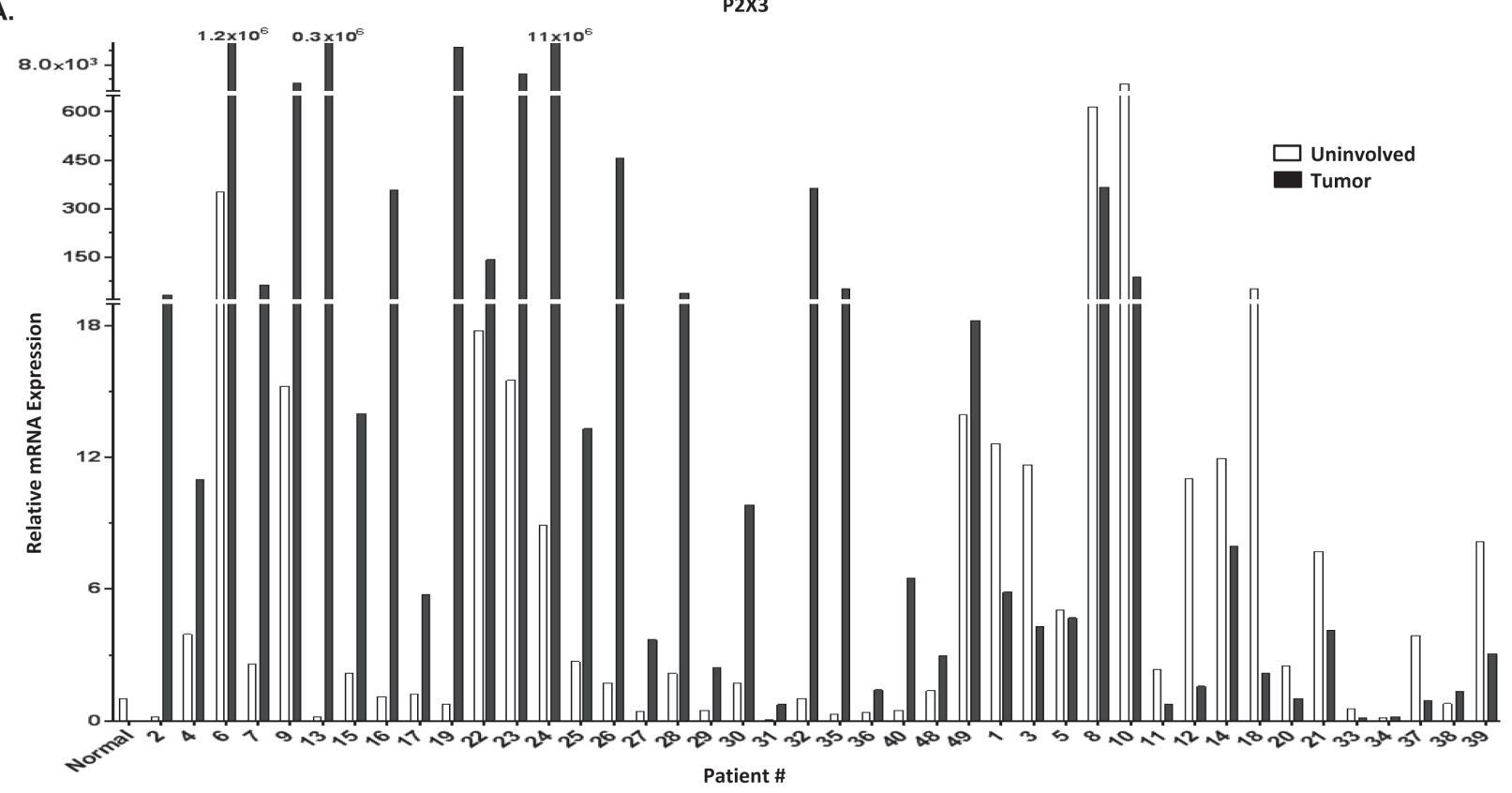

B.

\begin{tabular}{|c|c|c|c|c|c|c|c|c|c|c|c|c|c|}
\hline \multicolumn{2}{|c|}{17} & \multicolumn{2}{|c|}{25} & \multicolumn{2}{|c|}{29} & \multicolumn{2}{|c|}{30} & \multicolumn{2}{|c|}{36} & \multicolumn{2}{|c|}{47} & & \multirow{2}{*}{ — Patient \# } \\
\hline$T$ & U & $\begin{array}{ll}T \\
\end{array}$ & u & $\mathrm{T}$ & u & $T$ & u & $\begin{array}{lll}T & \end{array}$ & U & $\mathbf{N}$ & $\underline{\mathbf{N}}$ & $\begin{array}{c}\text { Hep } \\
\text { G2 }\end{array}$ & \\
\hline  & 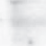 & - & - & & & & & & & & 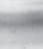 & $\longrightarrow$ & - P2X3 \\
\hline
\end{tabular}
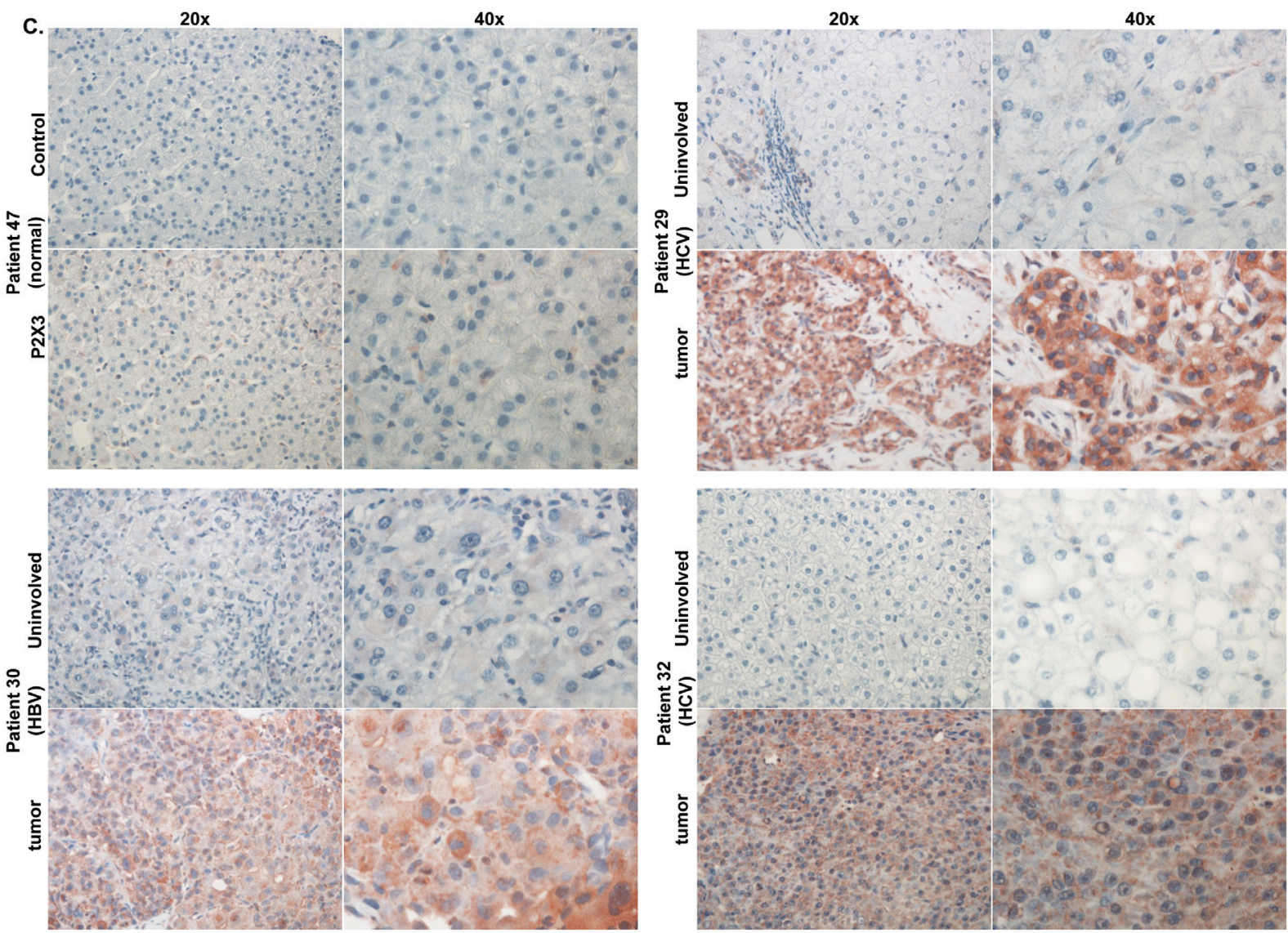
D.

P2X3 mRNA Expression in TMC Cohort

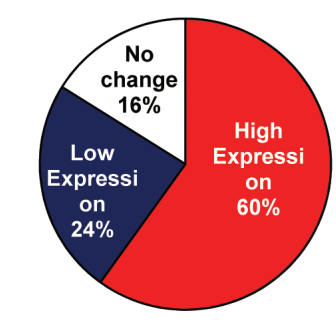

E.

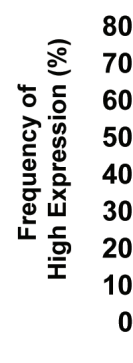
$P 2 \times 3$

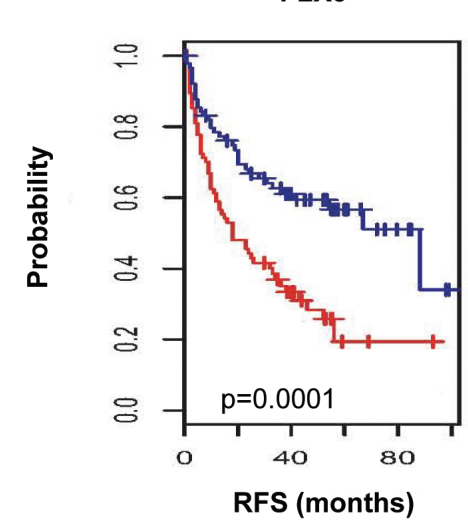

P2X3

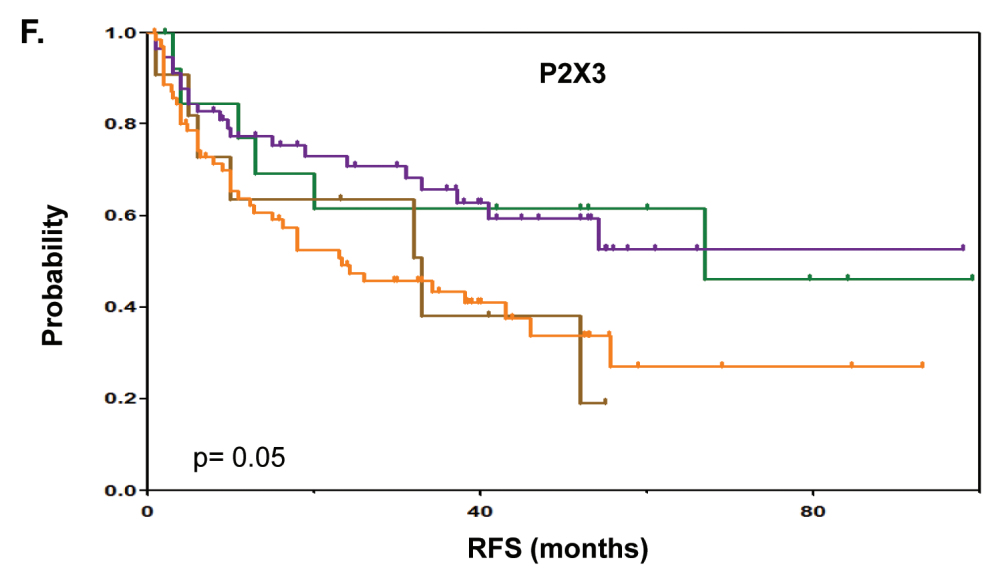

P2Y13

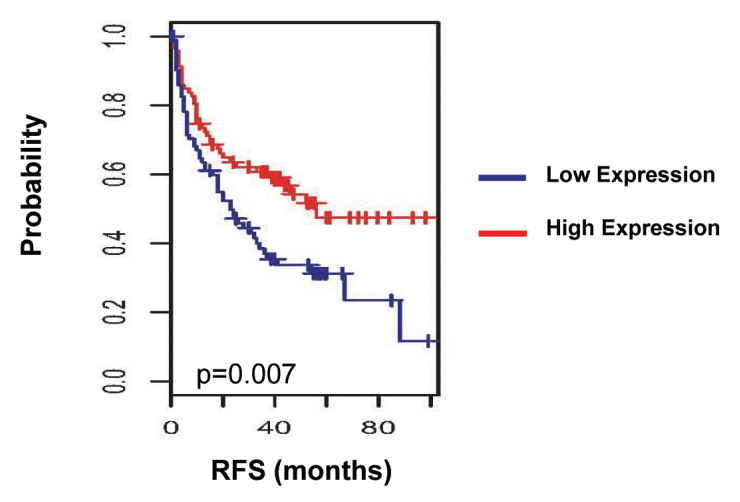

P2Y13 mRNA Expression in TMC Cohort

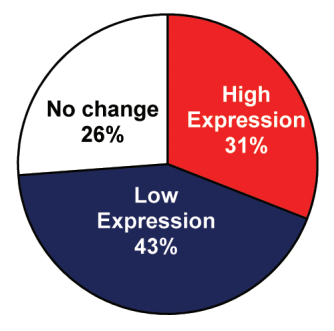

-HCV only

$\triangle$ Non viral only

$\mathrm{HBV}^{+}$, Low Expression

$\mathrm{HBV}^{-}$, Low Expression

$\mathrm{HBV}^{+}$, High Expression

HBV $^{-}$, High Expression

Figure 1: Increased P2X3 purinergic receptor mRNA expression is associated with poor recurrence-free survival in HCC patients. A. RNA isolated from HCC tumors, adjacent uninvolved areas and normal livers were analyzed by qRT-PCR. Relative mRNA expression was calculated with reference to normal livers. B. Western Blotting of total proteins isolated from TMC cohort patient tumor (T, $20 \mu \mathrm{g}$ ), uninvolved areas (U, $20 \mu \mathrm{g}$ ), normal liver tissue (N, $20 \& 45 \mu \mathrm{g}$ ) and HepG2 cells (20 $\mu \mathrm{g})$. C. Immunohistochemical analysis of P2X3 expression in normal human liver and TMC cohort liver tumors. D. Recurrence-free survival analysis (Kaplan-Meier) of Korean patient cohort; 'high' (above median) $v s$ 'low' (below median) expression of P2X3 and P2Y13 in HCC tumors, $n=188$. Distribution of P2X3 and PY13 mRNA expression in TMC patient cohort, $n=42$. E. Frequency of 'high' ( $\geq 2$-fold) P2 purinergic receptor mRNA expression, as compared to uninvolved areas in HCC tumors of patients with HCV vs. non-viral etiologies. F. Recurrence-free survival analysis (Kaplan-Meier) of Korean patient cohort; 'low' P2X3 (below median) and HBV positive $v s$ 'low' P2X3 (below median) and HBV negative vs 'high P2X3 (above median) and HBV positive $v s$ 'high P2X3 (above median) and HBV negative in HCC tumors, $n=156$. 
A.

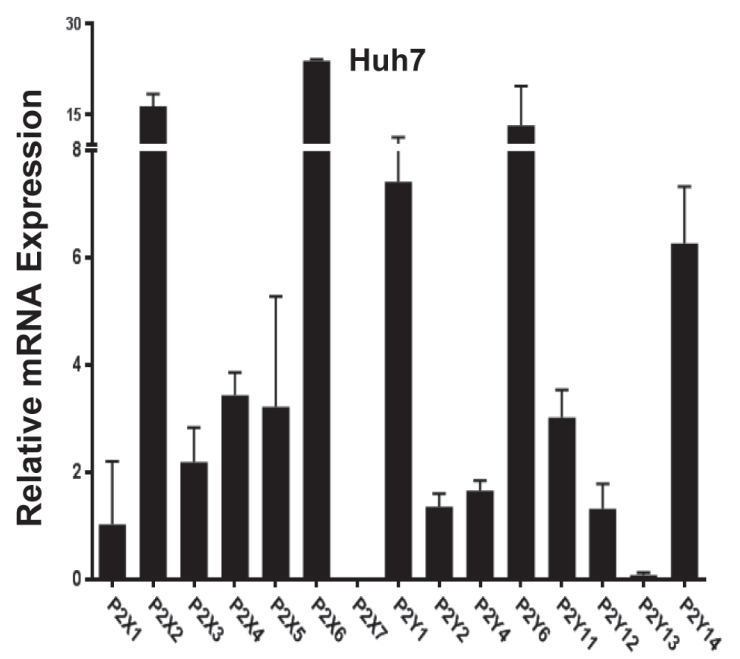

C.

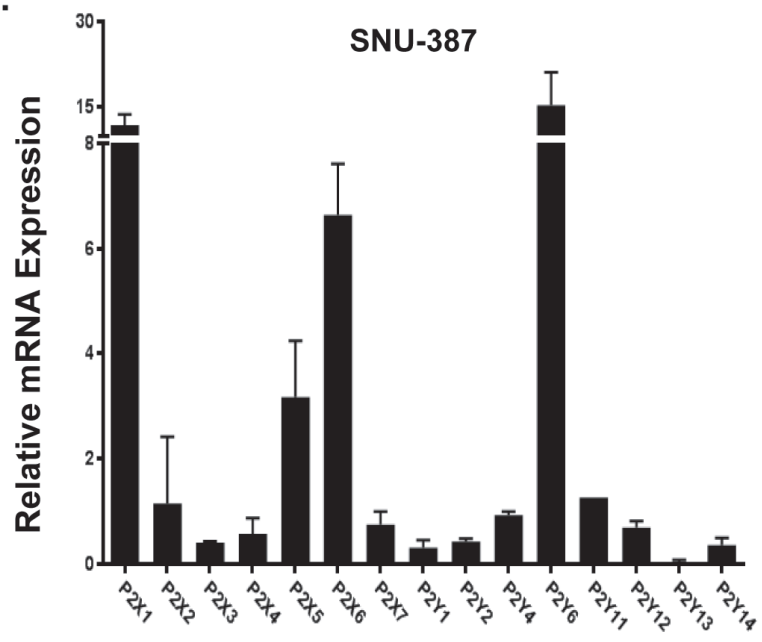

B.

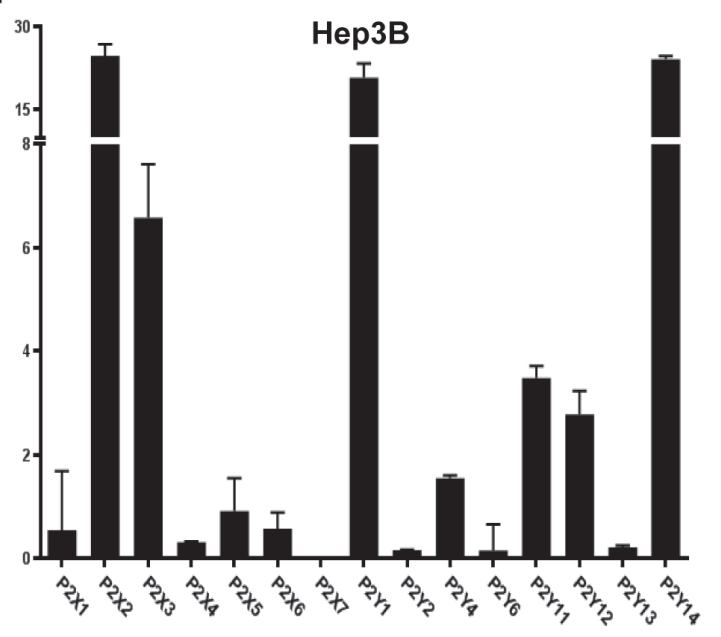

D.

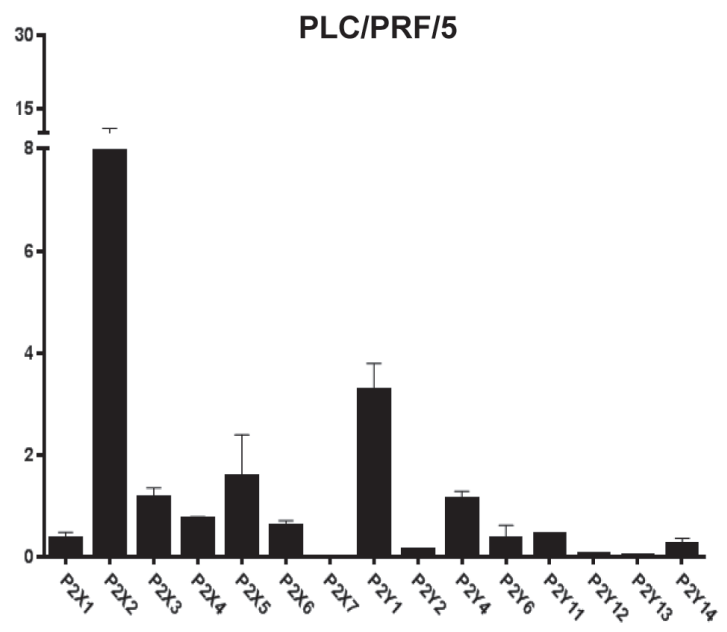

E.

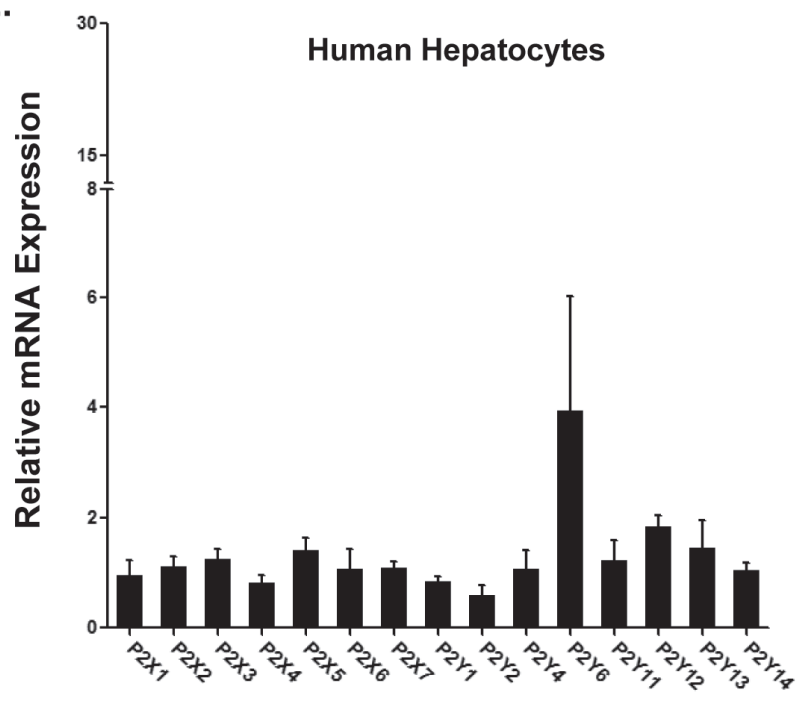

Figure 2: Dysregulation of $\mathbf{P 2}$ purinergic receptor expression in HCC cell lines. RNA isolated from A. Huh7, B. Hep3B, C. SNU-387, D. PLC/PRF/5 was analyzed by qRT-PCR for mRNA expression and relative expression was calculated with reference to primary hepatocytes isolated from normal healthy adults $(n=4)$. E. Total RNA isolated from freshly-frozen primary human hepatocytes (healthy adults with no known HCC; $n=4$ ) were analyzed by qRT-PCR for all 15 isoforms of P2 purinergic receptors. Purinergic receptor mRNA expression was calculated with reference to GAPDH, housekeeping gene. 
high (33 months) and P2X3 low (67 months) among HBV viral patients, there was no statistically significant difference in RFS between the two, likely due to small sample size (25 patients) (Suppl. Figure 3B). To determine whether the impact of P2X3 overexpression on risk of recurrence was dependent of HBV status Cox proportional hazard model analysis was performed. Our data reveals that there was no significant interaction between P2X3 expression and HBV status $(p=0.90)$, confirming that the effect of P2X3 high expression on the risk of recurrence does not significantly differ across HBV groups.

\section{Dysregulation of P2 purinergic receptor expression in $\mathrm{HCC}$ cells}

To determine if dysregulation of P2 purinergic receptor expression is associated with hepatocyte transformation to HCC phenotype and to identify a suitable in vitro model system for mechanistic studies, we analyzed P2 purinergic receptor mRNA expression by qRT-PCR in four human hepatocellular carcinoma cell lines - Huh7, Hep3B, SNU-387, PLC/PRF/5, and normal human primary hepatocytes. Suggesting a role for P2 purinergic receptors in hepatocyte transformation, all four HCC cell lines had upregulation of multiple P2 purinergic receptor isoforms and lower expression of P2Y13. Huh7, Hep3B and PLC/PRF/5 had lower expression of P2X7 and upregulation of P2X2 (Figure 2A-2D). Relative mRNA expression of all 15 purinergic receptor isoforms was comparable in normal human primary hepatocytes (Figure 2E).

\section{Extracellular nucleotides induce proliferation and cell-cycle progression in $\mathrm{HCC}$ cells}

To determine whether P2 purinergic receptor activation influences $\mathrm{HCC}$ cell proliferation, BrdU incorporation was assessed in HCC cells maintained in SFM for $24 \mathrm{~h}$ and treated with ATP for $24 \mathrm{~h}$. ATP treatment alone was sufficient to induce proliferation in each of these cell lines (Huh7, 34\%; Hep3B, 46\%; SNU-387, 47\% and $\mathrm{PLC} / \mathrm{PRF} / 5,24 \%$ ), identifying nucleotides as liver cancer cell mitogens (Figure 3A). Extracellular ATP can be hydrolyzed to ADP and adenosine by ectonucleotidases at the plasma membrane. Therefore, we tested the effects of ATP $\gamma \mathrm{S}$ (non-hydrolyzable analog of ATP) or ADP (break down product of ATP) $(100 \mu \mathrm{M})$ on Huh7 cell proliferation. ATP $\gamma \mathrm{S}$ treatment alone was sufficient to induce BrdU incorporation as early as $12 \mathrm{~h}(42 \%)$; maintained at $18 \mathrm{~h}(30 \%)$ and $24 \mathrm{~h}(29 \%)$ in Huh7 cells (Suppl. Figure 4). ADP was also able to independently increase the number of BrdU positive nuclei (12h, 30\%; 18h, 35\%; 24h, 37\%) (Suppl. Figure 4). Furthermore, ATP treatment $(18 \mathrm{~h})$ increased cell proliferation and viability in all four cell lines as determined by MTT assay (Huh7,
65\%; Hep3B, 81\%; SNU-387, 90\% and PLC/PRF/5, 43\%) (Figure 3B). In human hepatocytes, ATP treatment (18h) led to a modest increase in cell proliferation and viability $(27 \%)$ while ATP $\gamma \mathrm{S}$ treatment (18h) was more potent (64\%) (Figure 3C).

Nucleotide treatment resulted in increased cyclin D3, cyclin E, cyclin A and cyclin B mRNA expression, correlating with increased proliferation (Figure 3D). Cyclin D3 mRNA expression was observed after $6 \mathrm{~h}$ (ATP $\gamma \mathrm{S}-2.1$ fold), $12 \mathrm{~h}$ (ATP $\gamma \mathrm{S}-1.8$ fold; ADP - 2.7 fold), 24h (ATP $\gamma \mathrm{S}$ - 3.4 fold; ADP - 4.5 fold), 36h (ATP $\gamma \mathrm{S}-3.5$ fold; ADP - 2.8 fold) and 48h (ADP - 2.4 fold) treatment, as compared to untreated cells (Figure 3E). Cyclin E expression exhibited a similar profile while cyclin B expression was induced later at $36 \mathrm{~h}$ and $48 \mathrm{~h}$ after treatment (Figure 3E). Western blotting of Huh7 cell total lysates revealed that ATP $\gamma \mathrm{S}$ treatment (18h, 24h, 30h) alone was sufficient to induce cyclin D3 $(2.7,2.8,2.1$ fold), cyclin $\mathrm{E}(1.7,1.3,2.2$ fold) and cyclin A (1.7, 1.2, 1.2 fold) protein expression (Figure $3 \mathrm{~F})$. ATP $\gamma \mathrm{S}$ treatment (30h) induced CDK2 (1.6 fold) and CDK4 (1.4 fold) protein expression. Additionally, ATP treatment alone was sufficient to induce cyclin D3 protein expression in three of the four HCC cell lines tested; Huh7 (3.2 fold), SNU-387 (1.6 fold) and PLC/PRF/5 (1.4 fold)) (Suppl. Figure 5). ATP $\gamma \mathrm{S}$ treatment (24h) of human hepatocytes induced cyclin D3 (2.0 fold) and cyclin E (2.0 fold) protein expression (Figure $3 \mathrm{G}$ ). These data suggest that nucleotide treatment alone was sufficient to promote cell cycle progression and proliferation in human hepatocytes as well as liver cancer cells.

To confirm that nucleotide effects on dysregulation of cyclin expression is mediated via the activation of P2 purinergic receptors, cells were treated with a broad spectrum P2 purinergic receptor antagonist - suramin, prior to nucleotide treatment. Suramin pre-treatment resulted in a dose dependent attenuation of cyclin D3 mRNA induction (Figure 3H). Suramin treatment alone reduced baseline cyclin D3 expression (Figure $3 \mathrm{H}$ ), suggesting a role for endogenous ATP release and extracellular nucleotide signaling in basal Huh7 cell cycle progression.

\section{Nucleotides induce cyclin expression via c-Jun $\mathrm{N}$-terminal kinase (JNK) signaling in $\mathrm{Huh} 7$ cells}

We have previously shown that extracellular nucleotide-mediated activation of JNK signaling induces cell-cycle progression and proliferation of rat primary hepatocytes in vitro [11]. To determine whether extracellular nucleotides induce JNK signaling in transformed hepatocytes, Huh7 cells were treated with nucleotides for 5, 15 and $30 \mathrm{~min}$ and total protein extracts were analyzed by Western blotting for JNK phosphorylation (Ser ${ }^{\mathrm{Th} / \mathrm{Tyr}}$ ). ATP $\gamma \mathrm{S}$ treatment alone was 
A.

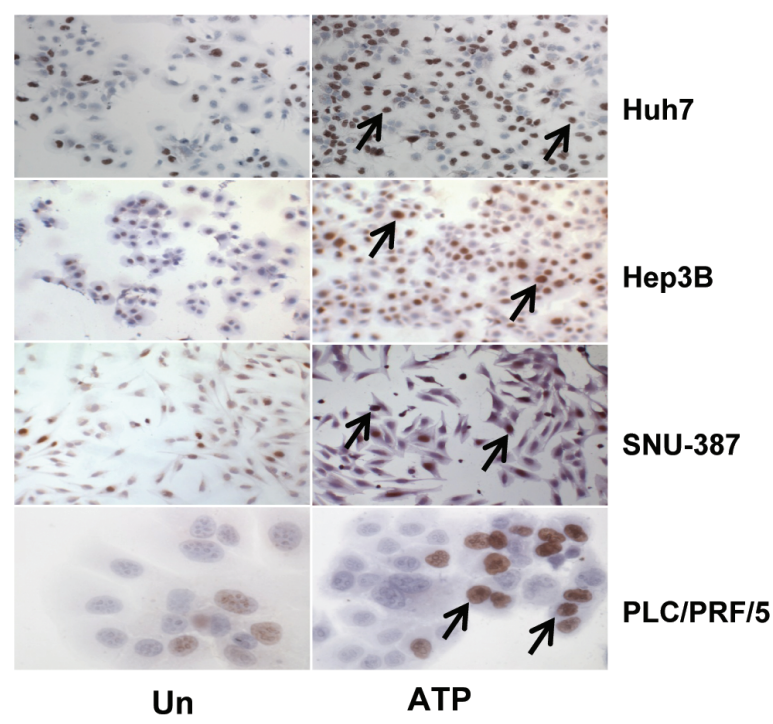

B. Human Hepatocellular Carcinoma Cell Lines

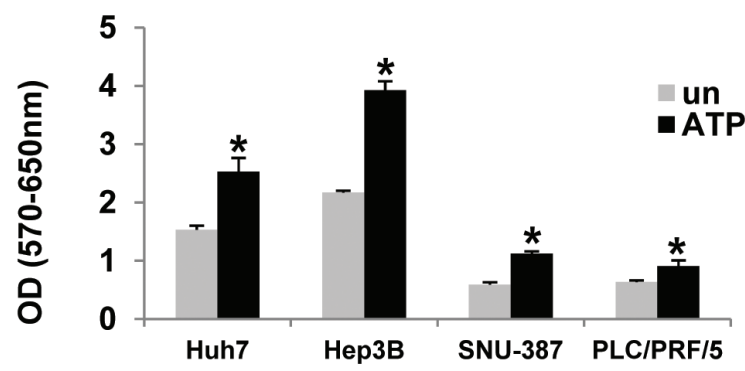

BrdU Incorporation in Hepatocellular Carcinoma Cell Lines

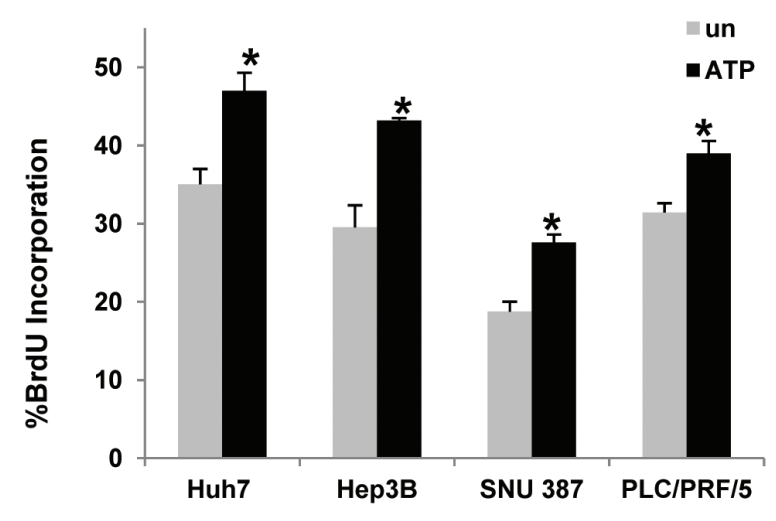

C. Human Hepatocytes

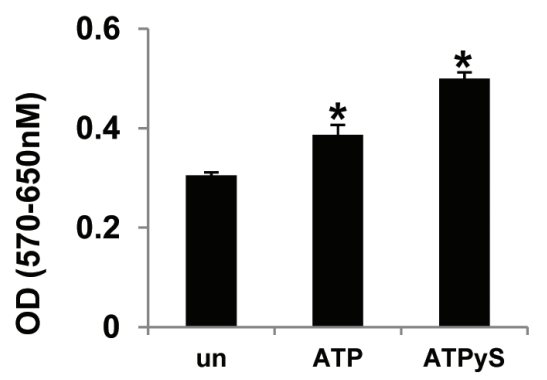

D.

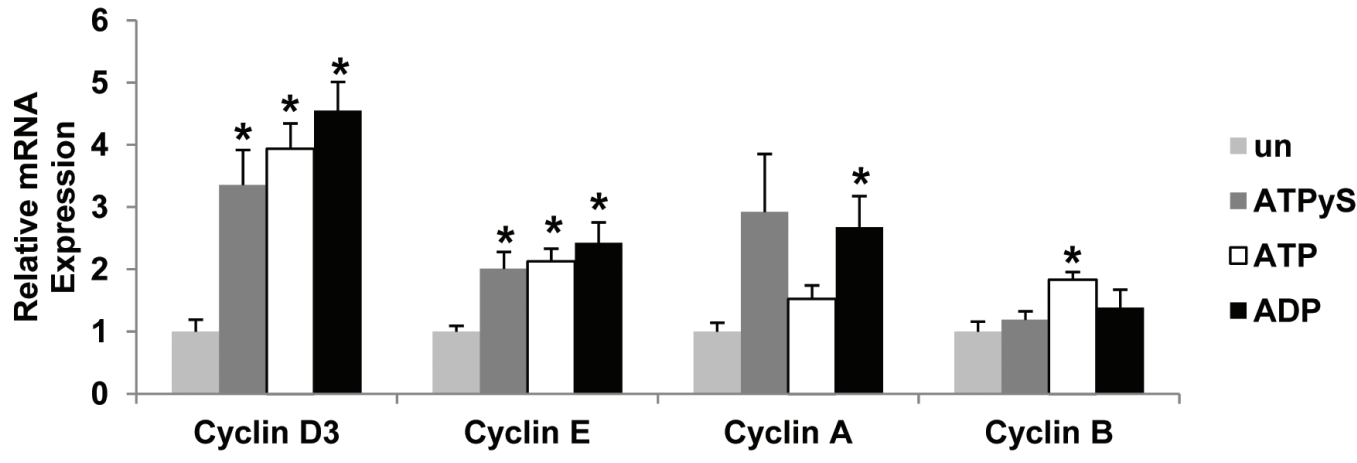

E.
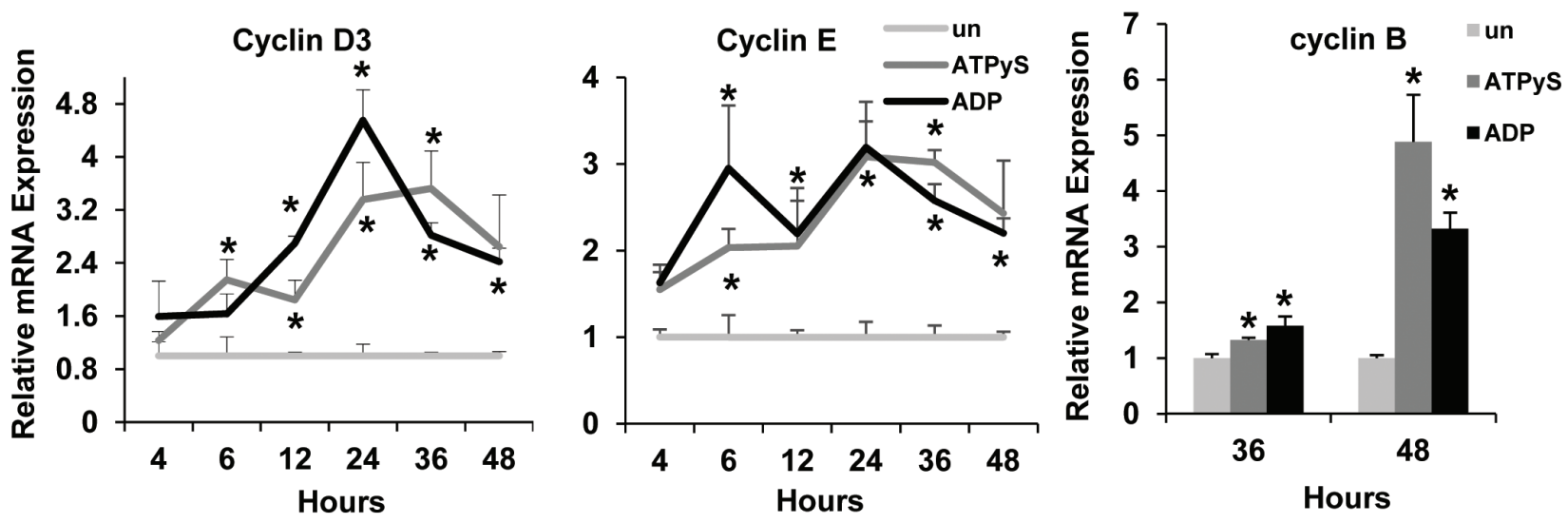
F.
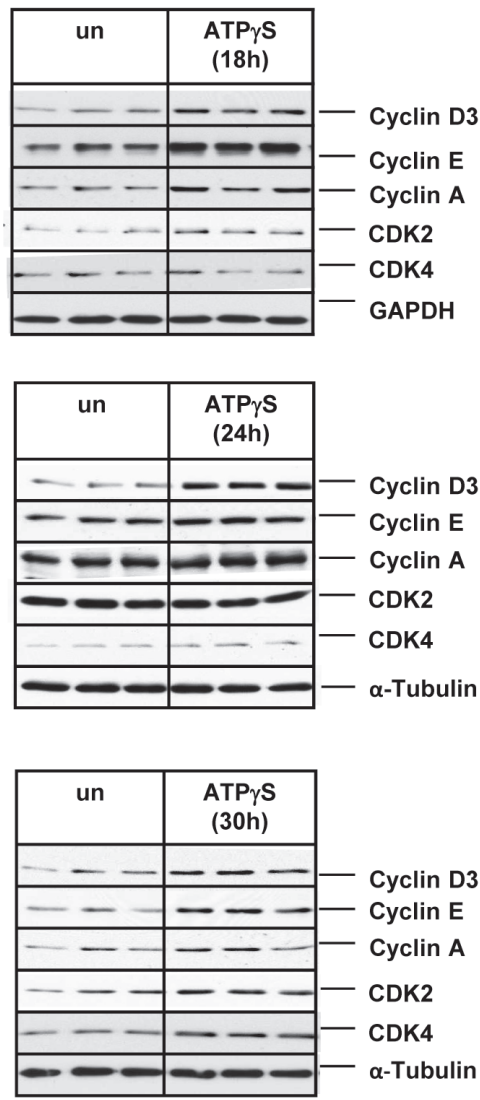
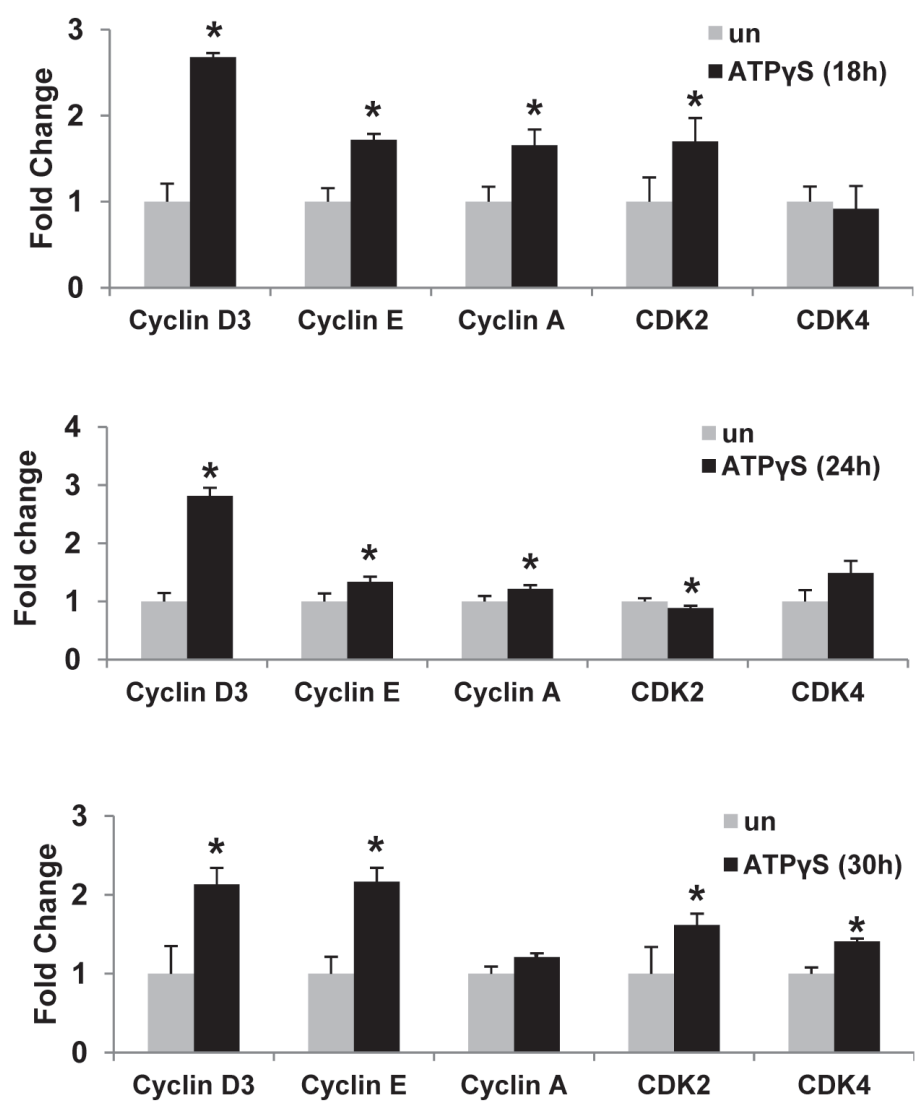

G.


H.

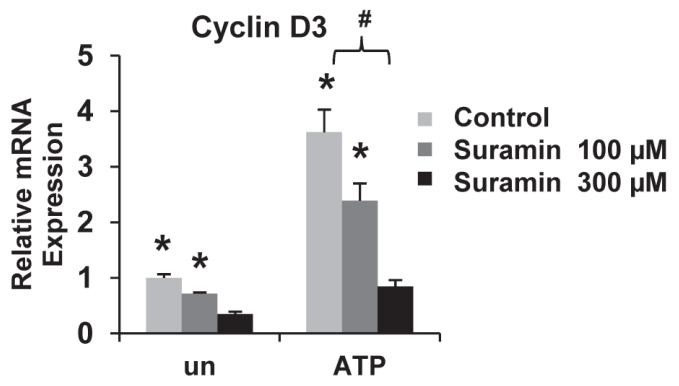

Figure 3: Extracellular nucleotides induce cell-cycle progression and proliferation in liver cancer cell lines. A. HCC cells after 24h of ATP treatment. Light microscopic images (Huh7, Hep3B, SNU-387 -10X; PLC/PRF/5 - 40x) of BrdU immunostained cells, expressed as a percentage of total cells. Arrows point to nuclei with BrdU staining. B. HCC cell proliferation after 18h ATP treatment, assessed by MTT assay. C. Human hepatocyte cell proliferation after $18 \mathrm{~h}$ ATP or ATP $\gamma$ S treatment, assessed by MTT assay. D. Total RNA isolated from Huh7 cells treated with ATP $\gamma \mathrm{S}$, ATP or ADP for $24 \mathrm{~h}$ and analyzed by quantitative RT-PCR for cyclin mRNA. E. Temporal expression of cyclin mRNA. F. Western blotting of total proteins from Huh7 cells after 18, 24 or 30h ATP $\gamma \mathrm{S}$ treatment. G. Western blotting of total proteins from human hepatocytes after $24 \mathrm{~h} \mathrm{ATP} \gamma \mathrm{S}$ treatment. H. Cyclin mRNA expression in Huh7 cells after 24h of nucleotide treatment \pm pre-treatment $\left(30 \mathrm{~min}\right.$ ) with suramin. Data represented as the mean $\pm \mathrm{SEM}, n=3,{ }^{*} p<0.05 v s$. untreated, ${ }^{*} p<0.05$. 
sufficient to induce JNK phosphorylation as early as 15 min (1.7 fold) (Figure 4A). ADP treatment resulted in similar induction (15 min - 2 fold).

To determine if extracellular nucleotide-mediated activation of JNK signaling influences cell-cycle progression in transformed hepatocytes, Huh7 cells were treated with SP600125 (JNK inhibitor) prior to ATP $\gamma \mathrm{S}$ treatment. Efficiency of JNK inhibition in Huh7 cells was confirmed by Western blotting for p-c-Jun. JNK inhibition completely attenuated ATP $\gamma \mathrm{S}$-mediated induction of cyclin D3, E and A proteins (Figure 4B) identifying a role for the activation of JNK signaling pathway in $\mathrm{P} 2$ purinergic receptor-mediated induced cell-cycle progression in Huh7 cells.

\section{P2X3 antagonism attenuates nucleotide-induced proliferation and cell cycle progression}

Prompted by our identification of P2X 3 as the most frequently overexpressed purinergic receptor isoform in human HCC tumors in our TMC cohort and that P2X3 overexpression is associated with poor recurrencefree survival in our Korean cohort, we performed a series of mechanistic studies in Huh7 cells in vitro, to determine the functional significance of P2X3 and its role in nucleotide-induced proliferation. Huh7 cells were treated with a highly selective P2X3 antagonist AF-353 prior to ATP treatment. Implicating P2X3 receptors in nucleotide-mediated proliferation, AF-353 pre-treatment completely abolished ATP-mediated increase in BrdU incorporation in Huh7 cells (Figure 5A). Similarly, ATPmediated induction of BrdU incorporation in Hep3B cells was completely attenuated by pre-treatment with P2X3 antagonist (Suppl. Figure 6). ATP-mediated induction of cyclin D3 and cyclin E expression were completely attenuated in Huh7 cells and human hepatocytes pretreated with AF-353 (Figure 5B). Our observations that P2X3 agonist 2-MeSATP treatment alone was sufficient to induce cyclin D3 expression (1.9 fold) and pre-treatment with an alternative P2X3 antagonist, A317491 attenuated ATP induced cyclin D3 expression in Huh7 cells further validates the role of $\mathrm{P} 2 \mathrm{X} 3$ purinergic receptor activation in the induction of cell-cycle progression in HCC cells (Figure 5C \& 5D) [32-34].

Interestingly, P2X3 antagonist treatment alone was sufficient to reduce the baseline BrdU-positive cells and cyclin protein expression in serum-free conditions, implicating P2X3 activation as a necessary facilitator of Huh7 cell cycle progression (Figure 5A-5B). Additionally, P2X3 antagonist treatment alone resulted in increased cleaved PARP protein expression, an established marker of cells undergoing apoptosis (Figure 5E).

\section{P2X3 overexpression increases basal and ATP mediated cell proliferation}

To confirm $\mathrm{P} 2 \mathrm{X} 3$ receptor involvement in $\mathrm{HCC}$ cell proliferation, $\mathrm{P} 2 \mathrm{X} 3$ was overexpressed in Huh7 cells then these cells were treated with ATP +/- P2X3 antagonist, $\mathrm{AF}-353$. BrdU analysis revealed that $\mathrm{P} 2 \mathrm{X} 3$ overexpression (72h post-transfection) alone was sufficient to significantly increase proliferation (51\%) compared the vector control pCMV6 (38\%). AF-353 treatment (24h) completely attenuated the P2X3 mediated increase in proliferation (Figure 6A). ATP Treatment (24h) further increased BrdU incorporation when compared to the pCMV6 control. ATP mediated proliferation was significantly higher in cells overexpressed with P2X3 compared to those transfected with only pCMV6. Again, pre-treatment with AF-353 significantly attenuated the ATP mediated increase in BrdU incorporation. Furthermore, P2X3 overexpression alone was sufficient to improve cell proliferation and viability of Huh7, Hep3B and PLC/PRF/5 cells as assessed by MTT assay (Figure 6B)

Collectively, these findings suggest that P2X3 purinergic receptor expression and function is critical for HCC cell survival and basal proliferation as well as proliferation in response to changes in nucleotide concentrations in the extracellular milieu.

\section{DISCUSSION}

In this study, we undertook a comprehensive analysis of all $15 \mathrm{P} 2$ purinergic receptor isoforms in HCC tumors, as compared to the adjacent uninvolved areas of HCC livers as well as normal livers. Our studies have identified a distinct dysregulation of $\mathrm{P} 2$ purinergic receptor expression in HCC livers. The upregulation of P2 purinergic receptor expression observed among the tumor samples when compared to their adjacent uninvolved areas highlights its significance in the pathogenesis of HCC. Altered P2 purinergic receptor expression in the uninvolved areas of HCC livers (as compared to normal healthy livers) suggests that purinergic signaling may be dysregulated prior to HCC development. Therefore, as potential biomarkers, P2 purinergic receptor upregulation has the advantage of being detected prior to tumor development when effective interventions may be undertaken. Another significant finding of this study is that there is a higher frequency of $\mathrm{P} 2$ purinergic receptor upregulation in $\mathrm{HCC}$ tumors of HCV patients, as compared to those tumors with non-viral etiologies, identifying a specific subgroup of $\mathrm{HCC}$ with higher prevalence of $\mathrm{P} 2$ purinergic receptor overexpression. However, immunohistochemical analysis suggests that $\mathrm{P} 2 \mathrm{X} 3$ overexpression is evident in $\mathrm{HCC}$ tumors, irrespective of viral status. Further studies in larger patient cohorts are required to determine the impact of viral infection on the dysregulation of $\mathrm{P} 2$ purinergic 
A.
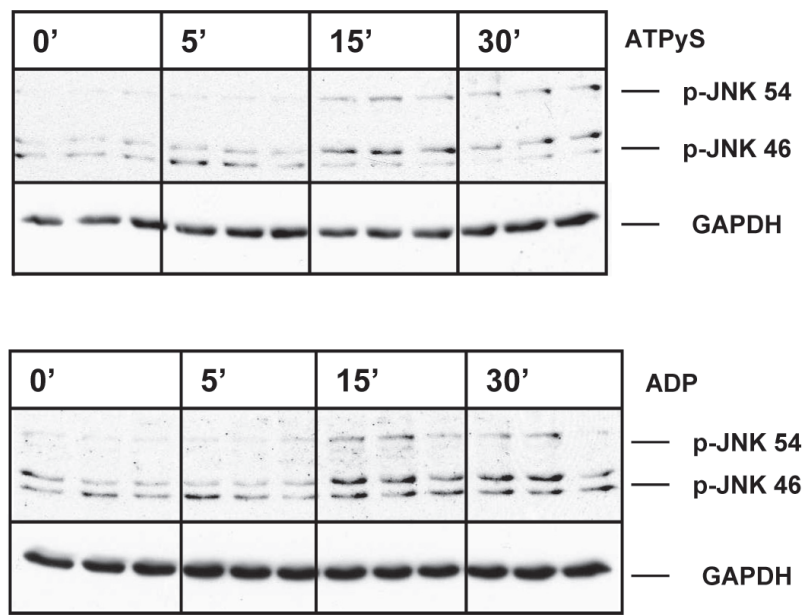


B.

\begin{tabular}{|c|c|c|c|c|}
\hline un & ATP $\gamma$ & $\begin{array}{c}\text { ATP } \gamma \\
+ \\
+ \\
\text { SP600125 }\end{array}$ & SP600125 & \\
\hline$-\cdots$ & $-\cdots$ & $-\cdots$ & $-\cdots$ & - Cyclin D3 \\
\hline$\therefore-\ldots$ & --- & --- & -1 & - Cyclin E \\
\hline--1 & --- & $-\cdots$ & $--\infty$ & - $C_{y c l i n} \mathrm{~A}$ \\
\hline--- & --- & $=$ & & - p-c-Jun (Sere \\
\hline & $-\infty-$ & $-\infty$ & $p \rightarrow$ & - $a$-Tubulin \\
\hline
\end{tabular}

Cyclin D3

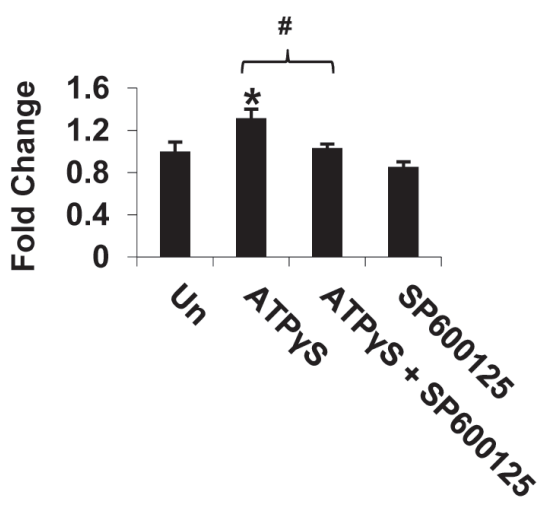

Cyclin E

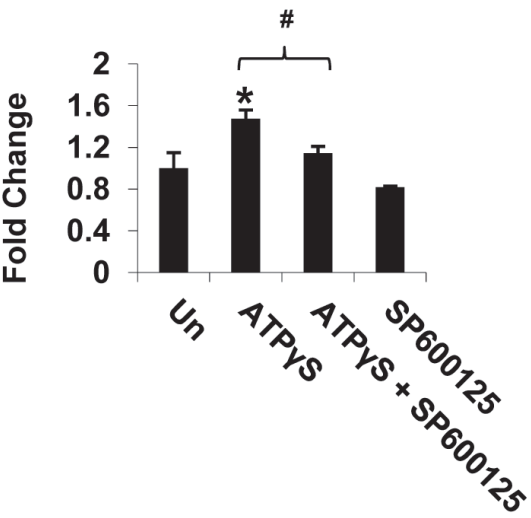

Cyclin A

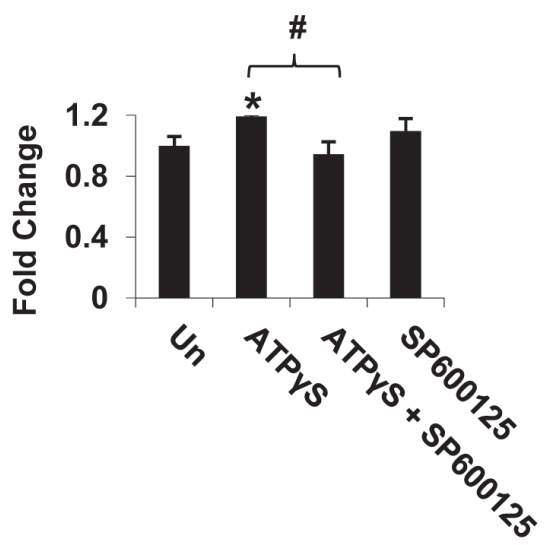

Figure 4: Extracellular nucleotides induce cell-cycle progression via activation of JNK signaling in Huh7 cells. Western Blotting of total protein extracts of Huh7 cells after A. 5, 15 and 30min of ATP $\gamma \mathrm{S}$ or ADP treatment $(100 \mu \mathrm{M})$, B. ATP $\gamma \mathrm{S}(24 \mathrm{hr}) \pm$ pretreatment (30 min) of JNK inhibitor, SP600125 (30 $\mu \mathrm{M})$. 
A.

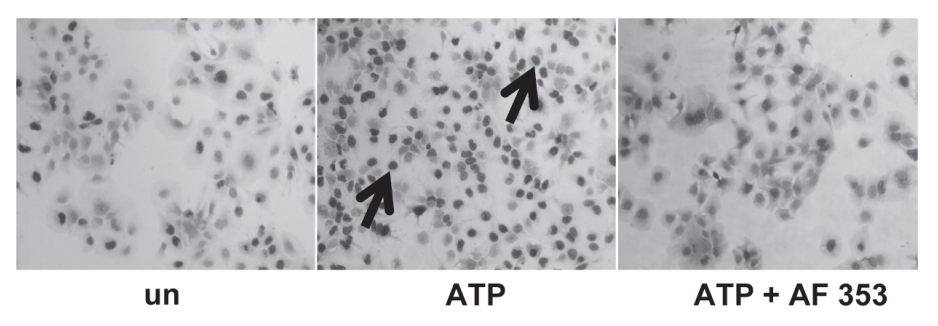



Human Hepatocytes
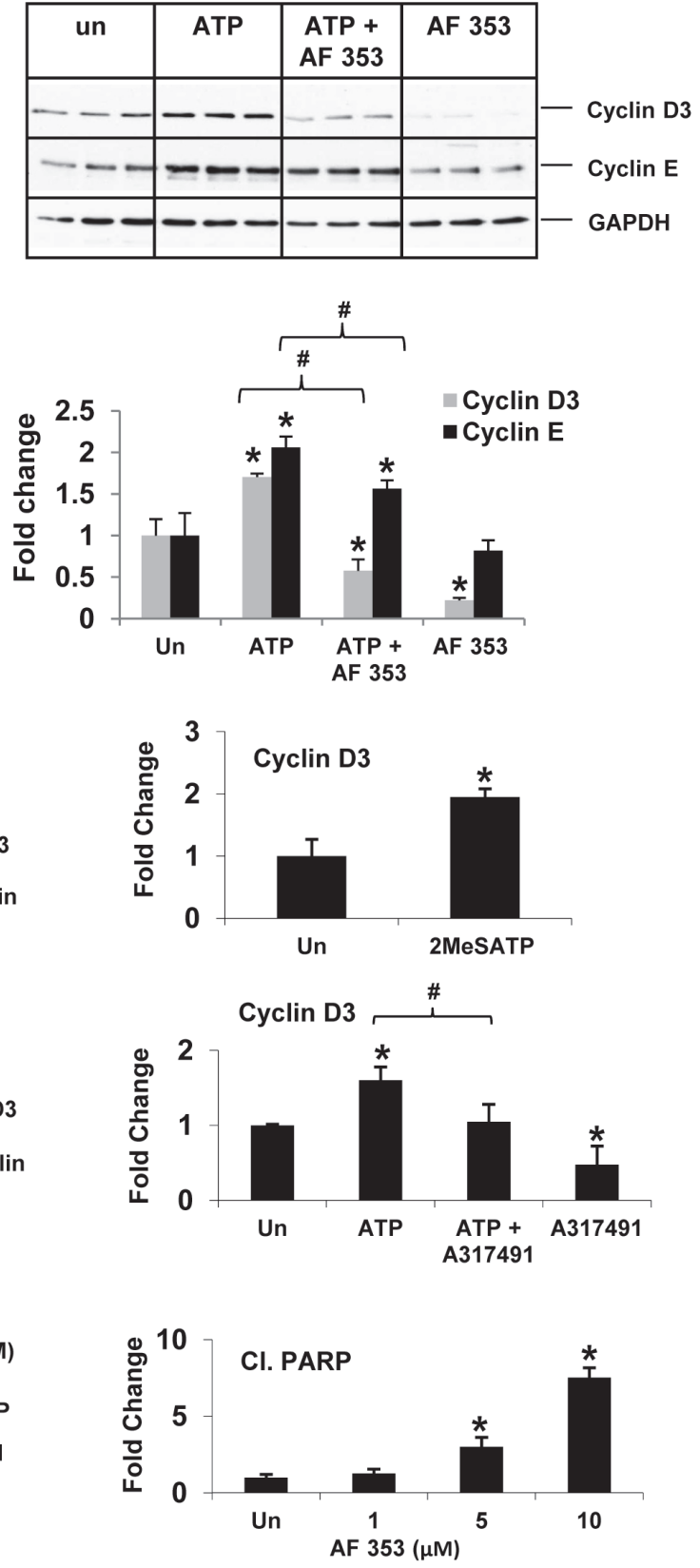

Figure 5: P2X3 antagonist, AF-353, attenuates ATP-mediated induction of Huh7 cell proliferation. A. Light microscopic images (10X) of BrdU immunostained Huh7 cells after ATP (100 $\mu \mathrm{M}, 24 \mathrm{hr}) \pm$ pre-treatment with AF- $353(5 \mu \mathrm{M})$. Arrows point to BrdUpositive cells, expressed as a percentage of total cells. Data represents mean $\pm \mathrm{SEM}, n=3-6,{ }^{*} p<0.05 v s$. untreated. Western Blotting of


agonist, 2MeSATP $(50 \mu \mathrm{M})$, D. ATP \pm A317491 $(30 \mu \mathrm{M})$, E. P2X3 antagonist, AF- 353 alone. Data represents mean $\pm \mathrm{SD}, n=3,{ }^{*} p<0.05$ vs. untreated, ${ }^{\sharp} p<0.05$. 
receptor expression and its role in HCC pathogenesis.

Dysregulation of purinergic receptor expression may influence initiation and temporal progression of HCC via its influence on dysregulation of cell-cycle control, a hallmark of HCC cells. In this study, we have identified that $\mathrm{P} 2 \mathrm{X} 3$ purinergic receptor expression and function is critical for HCC cell survival and proliferation. Interestingly, P2X3 was the most frequently upregulated purinergic receptor isoform in our local TMC patient cohort. It was ranked in the top $7 \%$ of overexpressed genes in the Mas_Liver dataset (Oncomine) and its 'high' expression had the strongest correlation with decreased recurrence free survival in our Korean patient cohort
$[26,30]$. Therefore, P2 purinergic receptors can serve as potential new targets for the development of $\mathrm{HCC}$ therapeutics.

While purinergic signaling has been implicated in cancer, its influence on proliferation varies by cancer cell type and cell-type specific P2 purinergic receptor expression profile $[10,13,14,17-22]$. We observed differential P2 purinergic receptor expression profiles among the four HCC cell lines tested (Figure 2). This heterogeneity of purinergic receptor expression profile may dictate varying functional outcomes in cells, in response to nucleotide changes in the extracellular milieu. Activation of each receptor isoform elicits unique

A.
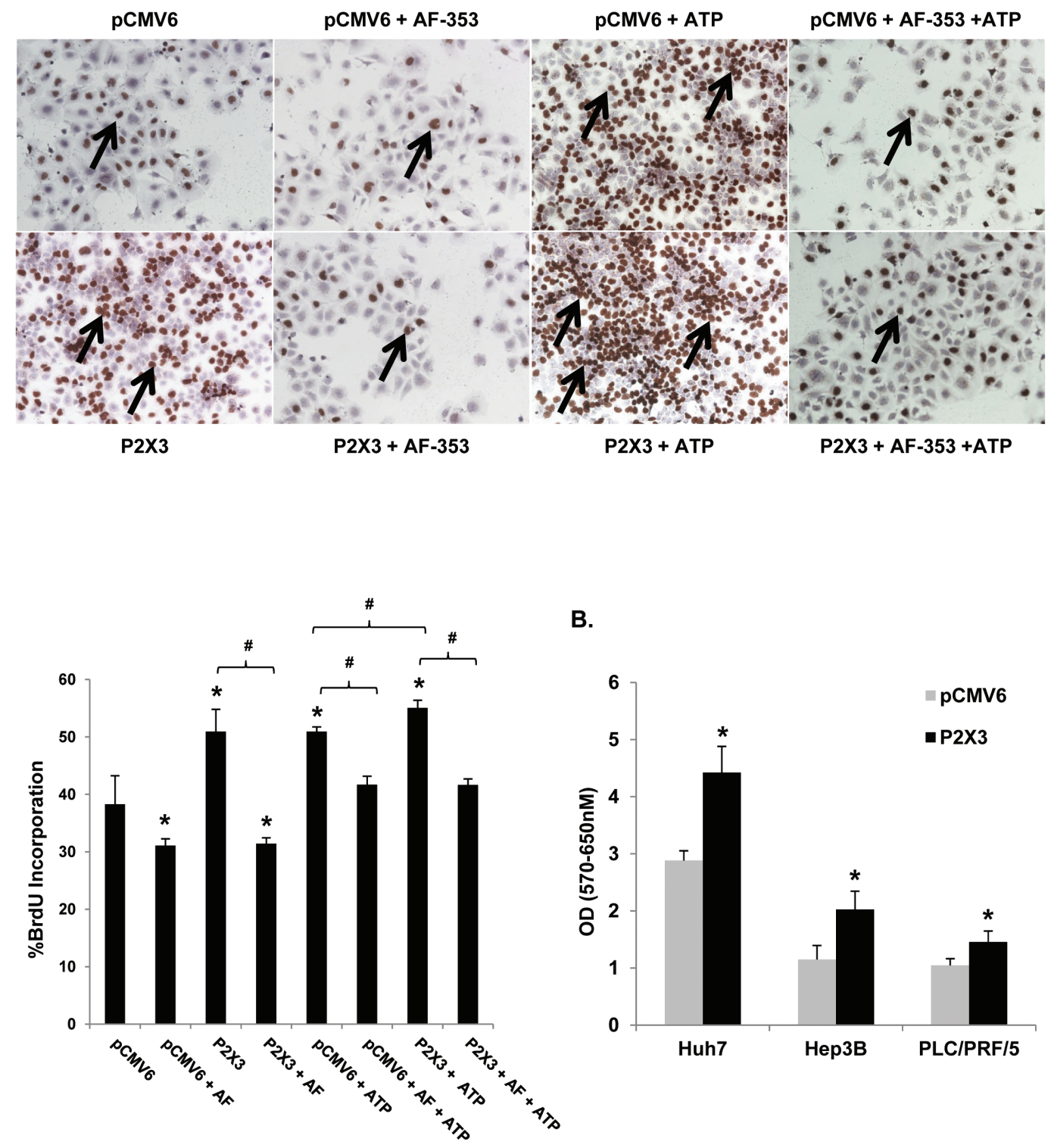

B.

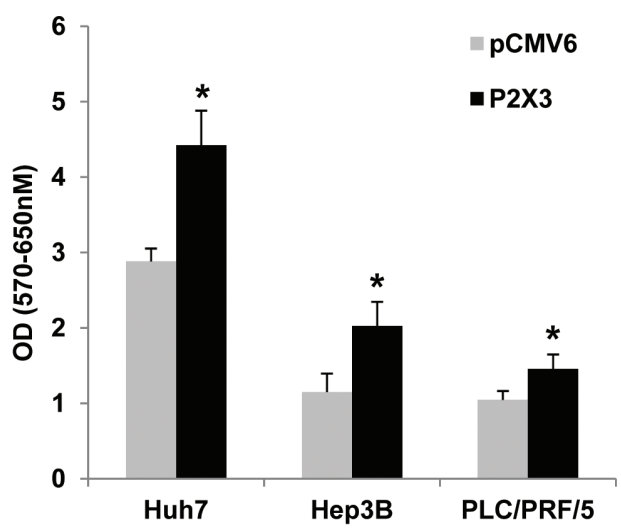

Figure 6: P2X3 overexpression induces basal and ATP mediated proliferation. A. Light microscopic images (10X) of BrdU immunostained Huh7 cells after pCMV6 plasmid or P2X3 DNA transfection \pm ATP $(100 \mu \mathrm{M}, 24 \mathrm{hr}) \pm$ pre-treatment with AF- $353(5 \mu \mathrm{M})$. Arrows point to BrdU-positive cells, expressed as a percentage of total cells. B. HCC cell proliferation after $72 \mathrm{~h}$ pCMV6 plasmid or P2X3 DNA transfection, assessed by MTT assay. Data represents mean \pm SEM, $n=3-6,{ }^{*} p<0.05 v s$. untreated. 
responses, such that a cancer cell may benefit from increased expression of some isoforms and decreased expression of others. Confirming previous findings, P2X7, and P2Y13 expression were reduced, as compared to the other receptor isoforms, in three of the four HCC cell lines tested $[35,36]$. P2X7 purinergic receptor activation induces apoptosis by increasing intracellular levels of $\mathrm{Ca}^{2+}$ in multiple cell types [10]. It is no surprise then that this receptor is down regulated in cancer cells as a means of avoiding cell death. In our TMC patient cohort, P2X7 had a lower frequency of upregulation (33\%), as did P2Y13 (31\%), as compared to other receptors such as P2X3 (60\%) (Table 1). Our data show a strong positive correlation between 'low' P2Y13 expression and increased recurrence free survival in our Korean cohort (Figure 1D). P2Y13 purinergic receptor, preferentially activated by ADP, has been shown to play a role in the activation of anti-oxidant $\mathrm{Nrf} 2 / \mathrm{HO}-1$ axis to protect against oxidative stress-induced neuronal death [37]. It is well established that oxidative stress contributes to the development of HCC and it is reported that patients with HCC that exhibit increased oxidative stress levels are prone to recurrence after 'curative' treatment [38, 39]. P $2 X 2$ expression was elevated in three HCC cell lines tested. Compared to the normal livers, P2X2 had the highest frequency of upregulation in HCC tumor tissues $(83 \%)$ (Table1). It is noteworthy that P2X2 often forms heteromultimeric complexes with $\mathrm{P} 2 \mathrm{X} 3$, the other highly overexpressed receptor in our TMC patient cohort [40]. Overall, $\mathrm{P} 2$ purinergic receptor expression is dysregulated in HCC cells commensurate with its hyper-proliferative transformed phenotype, as compared to quiescent hepatocytes isolated from normal healthy adult livers.

Our finding that extracellular nucleotides induce cyclin D3, cyclin E and cyclin A protein expression via activation of JNK signaling is of significant interest to our understanding of pathogenesis of $\mathrm{HCC}$, as it has been previously reported that JNK1 expression is increased in primary hepatocellular carcinomas [41, 42]. Cyclin D3 was reported to be upregulated in $51-72 \%$ of HCC tissues and was overexpressed in the Mas_liver dataset (Supp. Figure 7) [26, 43, 44]. Our in vitro studies suggest nucleotide induced cyclin D3 expression is mediated via activation of $\mathrm{P} 2 \mathrm{X} 3$ purinergic receptors in Huh7 cells. We show that nucleotide treatment induces CDK4 protein expression. Studies suggest that the function of CDK4 is most critical for $\mathrm{G}_{1} / \mathrm{s}$ HCC cell cycle progression and that CDK4 is activated by cyclins D and $\mathrm{E}[45,46]$.

P2X3 overexpression increases cell proliferation and viability, indicating for the first time the critical role of P2X3 receptors in HCC cell growth. These findings highlight the functional significance of increased P2X3 receptor expression in the tumors. Furthermore, the attenuation of $\mathrm{P} 2 \mathrm{X} 3$ mediated proliferation by $\mathrm{P} 2 \mathrm{X} 3$ antagonist, AF-353, clearly highlights the potential therapeutic application by pharmaceutical control of P2X3 receptor activation against $\mathrm{HCC}$ propagation.

$\mathrm{P} 2 \mathrm{X} 3$ receptor expression in afferent neurons and its role in pain sensation is well characterized [33]. Although P2X3 expression has been reported in hepatocytes, cholangiocytes, and portal vein myocyctes in the liver and liver derived cell lines, $\mathrm{P} 2 \mathrm{X} 3$ receptor function in hepatic cells has not been well characterized [36, 47-49]. Recently, $\mathrm{P} 2 \mathrm{X} 3$ has been reported to be involved in the complex regulation of liver regeneration through its expression on Natural Killer (NK) cells [50, 51]. It is reported that NK cells are reduced in the intratumoral tissue of $\mathrm{HCC}$ patients, particularly those with advanced stage HCC $[52,53]$. In the present study, we provide evidence for P2X3 overexpression in hepatocytes, as assessed by immunohistochemical analysis of HCC patient livers and its role in hepatocyte proliferation, as assessed by in vitro studies in human primary hepatocytes and four independent HCC-derived cell lines. Further studies are required to determine if $\mathrm{P} 2 \mathrm{X} 3$ purinergic receptor expression in immune cells infiltrating HCC tumors plays a role in $\mathrm{HCC}$ pathogenesis.

Considering previous findings of increased ATP concentrations in the extracellular milieu in injured and inflamed livers [8] and in the tumor interstitium [18], as well as our findings of increased P2 purinergic receptor expression in HCC liver tumors, our observations of nucleotide-mediated increased proliferation in HCC cells is particularly meaningful.

In conclusion, extracellular nucleotides via the activation of $\mathrm{P} 2$ purinergic receptors induce proliferation and cell cycle progression in HCC cells. P2 purinergic receptor expression is significantly dysregulated in HCC tumor tissues and exhibits strong correlation with recurrence-free survival in HCC patients. These studies underscore the potential role of purinergic signaling in the pathogenesis of HCC, and highlight the utility of P2 purinergic receptors as a potential new class of biomarkers and therapeutic targets.

\section{MATERIALS AND METHODS}

\section{HCC patients}

Liver tumors and adjacent, uninvolved areas (42 pairs) were obtained from HCC patients undergoing resection or liver transplantation at St. Luke's Episcopal Hospital and Ben Taub Hospital in the Texas Medical Center, Houston TX (TMC cohort). Normal livers (6 samples) were obtained from donor livers prior to transplantation at the St. Luke's Episcopal Hospital.

Tumor specimens were obtained from an additional 188 HCC patients undergoing hepatectomy at Seoul National University, Guro Hospital of Korea University, Seoul, Chonbuk National University, Jeonju, and Dong- 
San Medical Center of Keimyung University, Daegu, Korea (Korean cohort). Gene expression data from the Korean cohort were generated using the Illumina microarray platform human- 6 versions 2 and 4 (Illumina, San Diego, CA). These patients were followed up prospectively at least once every 3 months after surgery. Primary microarray data from the Korean cohort are available in NCBI's GEO public database (accession numbers GSE16757 and GSE43619). The study protocols were approved by the Institutional Review Boards of institutions, and all participants had provided written, informed consent.

\section{Oncomine database}

The Oncomine 4.5 (www.oncomine.org), a publicly available database of published cancer gene expression profiles, was queried for alterations in $\mathrm{P} 2$ purinergic receptor (P2X3, P2Y13) and cyclin D3 genes with additional filters defined for the analysis type (cancer $v s$ normal) and cancer type: liver cancer. Five gene expression and three DNA copy number datasets were retrieved for further analysis, comparing HCC vs normal [24-29]. All gene expression data were log-transformed and median-centered and all statistical analyses were performed using functions implemented in Oncomine. $\mathrm{P}$ value of less than $0.05(p<0.05)$ is considered significant [30].

\section{Hepatocytes, HCC cell lines and gene transfection}

Normal human primary hepatocytes isolated from healthy adults (no known history of HCC), in supsension or freshly frozen prior to shipment (Cryoport Systems, CA) were purchased from Triangle Research Labs, NC. Human hepatocellular carcinoma derived Huh7, Hep3B, SNU-387 and PLC/PRF/5, cell lines were maintained, as described in the Supplementary Methods.

\section{Immunohistochemistry, MTT assay and western blotting}

Formalin-fixed and paraffin embedded liver sections from HCC patients were analyzed by immunohistochemistry. HCC cell proliferation was evaluated by immunohistochemical analysis of $\mathrm{BrdU}$ incorporation and MTT assay; Total protein extracts of HCC cells were analyzed by Western blotting, as described in Supplementary Methods.

\section{Real-time quantitative reverse-transcriptase polymerase chain reaction (qRT-PCR)}

Total RNA was isolated from human livers or cells using Trizol Reagent according to manufacturer's instructions (Invitrogen, NY). Complementary DNA (cDNA) synthesis and qRT-PCR were performed, as described in Supplementary Methods.

\section{Statistical analysis}

Data was analyzed by one way analysis of variance (ANOVA) or unpaired Student's $t$ test. Values of $p<0.05$ were considered statistically significant. TMC cohort patients were stratified by P2 purinergic receptor expression ('high' - $\geq 2$-fold $v s$ 'low' - $\leq 0.5$ fold as compared to uninvolved areas). Korean cohort patients were stratified according to 'high' (above median) and 'low' (below median) expression for P2 Receptor gene expression and prognostic difference was assessed by Kaplan-Meier plots and log-rank test [31]. Cox proportional hazard model analysis was done on the Korean patient cohort to test the interaction between HBV status and $\mathrm{P} 2$ purinergic receptor expression on the risk of recurrence.

\section{FINANCIAL SUPPORT}

This study was supported by NIH RO1 DK069558 (ST), CPRIT Pre-Doctoral Training Grant RP101499 (JM), and DK56338, which funds the Texas Medical Center Digestive Diseases Center, Cade R. Alpard Foundation, Bauer Family Fund, Men of Distinction and Spain Fund for Pediatric Liver Research at Texas Children's Hospital.

\section{CONFLICTS OF INTEREST}

None

\section{REFERENCES}

1. Ferlay J SI, Ervik M, Dikshit R, Eser S, Mathers C, Rebelo M, Parkin DM, Forman D, Bray, F. (2013). GLOBOCAN 2012 v1.0, Cancer Incidence and Mortality Worldwide International Agency for Research on Cancer.

2. El-Serag HB and Rudolph KL. Hepatocellular Carcinoma: Epidemiology and Molecular Carcinogenesis. Gastroenterology. 2007; 132:2557-2576.

3. Schütte K, Bornschein J and Malfertheiner P. Hepatocellular Carcinoma - Epidemiological Trends and Risk Factors. Digestive Diseases. 2009; 27:80-92.

4. Artinyan A, Mailey B, Sanchez-Luege N, Khalili J, Sun CL, Bhatia S, Wagman LD, Nissen N, Colquhoun SD and Kim J. Race, ethnicity, and socioeconomic status influence the 
survival of patients with hepatocellular carcinoma in the United States. Cancer. 2010; 116:1367-1377.

5. Wörns MA and Galle PR. Future perspectives in hepatocellular carcinoma. Digestive and Liver Disease. 2010; 42, Supplement 3:S302-S309.

6. American Liver Foundation. 2012. [http://www. liverfoundation.org/abouttheliver/info/transplant/].

7. Fitz JG. Regulation of Cellular Atp Release. Transanctions of the American Clinical and Climatological Association. 2007; 118:199-208.

8. Cauwels A, Rogge, E., Vandendriessche, B., Shiva, S., Brouckaert, P. Extracellular ATP drives systemic inflammation, tissue damage and mortality. Cell Death and Disease. 2014; 5:7.

9. Gonzales E, Julien B, Serrière-Lanneau V, Nicou A, Doignon I, Lagoudakis L, Garcin I, Azoulay D, DuclosVallée J-C, Castaing D, Samuel D, Hernandez-Garcia A, Awad SS, Combettes L, Thevananther S and Tordjmann T. ATP release after partial hepatectomy regulates liver regeneration in the rat. Journal of Hepatology. 2010; 52:5462.

10. White $\mathrm{N}$ and Burnstock G. P2 receptors and cancer. Trends in Pharmacological Sciences. 2006; 27:211-217.

11. Thevananther S, Sun H, Li D, Arjunan V, Awad SS, Wyllie S, Zimmerman TL, Goss JA and Karpen SJ. Extracellular ATP activates c-jun N-terminal kinase signaling and cell cycle progression in hepatocytes. Hepatology. 2004; 39:393-402.

12. Tackett BC, Sun H, Mei Y, Maynard JP, Cheruvu S, Mani A, Hernandez-Garcia A, Vigneswaran N, Karpen SJ and Thevananther S. P2Y2 purinergic receptor activation is essential for efficient hepatocyte proliferation in response to partial hepatectomy. American Journal of Physiology - Gastrointestinal and Liver Physiology. 2014; 307:G1073-G1087.

13. Wei Q, Costanzi S, Liu Q-Z, Gao Z-G and Jacobson KA. Activation of the P2Y1 receptor induces apoptosis and inhibits proliferation of prostate cancer cells. Biochemical Pharmacology. 2011; 82:418-425.

14. Li H-j, Wang L-y, Qu H-n, Yu L-h, Burnstock G, Ni X, $\mathrm{Xu} \mathrm{M}$ and Ma B. P2Y2 receptor-mediated modulation of estrogen-induced proliferation of breast cancer cells. Molecular and Cellular Endocrinology. 2011; 338:28-37.

15. Joo YN, Jin H, Eun SY, Park SW, Chang KC and Kim HJ. P2Y2R activation by nucleotides released from the highly metastatic breast cancer cell MDA-MB-231 contributes to pre-metastatic niche formation by mediating lysyl oxidase secretion, collagen crosslinking, and monocyte recruitment. Oncotarget. 2014; 5:9322-9334.

16. Burnstock G and Di Virgilio F. Purinergic signalling and cancer. Purinergic Signal. 2013; 9(4):491-540.

17. Xie R, Xu J, Wen G, Jin H, Liu X, Yang Y, Ji B, Jiang Y, Song P, Dong H and Tuo B. P2Y2 Nucleotide Receptor Mediates the Proliferation and Migration of Human
Hepatocellular Carcinoma Cells Induced by ATP. Journal of Biological Chemistry. 2014; 289:19137-49.

18. Pellegatti P, Raffaghello L, Bianchi G, Piccardi F, Pistoia $\mathrm{V}$ and Di Virgilio F. Increased Level of Extracellular ATP at Tumor Sites: In Vivo Imaging with Plasma Membrane Luciferase. PLoS ONE. 2008; 3:e2599.

19. Beldi $\mathrm{G}$. The role of purinergic signaling in the liver and in transplantation: effects of extracellular nucleotides on hepatic graft vascular injury, rejection and metabolism. Frontiers in bioscience. 2008; 13:2588-2603.

20. Sun X, Han L, Seth P, Bian S, Li L, Csizmadia E, Junger WG, Schmelzle M, Usheva A, Tapper EB, Baffy G, Sukhatme VP, Wu Y and Robson SC. Disordered purinergic signaling and abnormal cellular metabolism are associated with development of liver cancer in Cd39/Entpd1 null Mice. Hepatology. 2013; 57:205-216.

21. Kunzli BM, Berberat PO, Giese T, Csizmadia E, Kaczmarek E, Baker C, Halaceli I, Buchler MW, Friess H and Robson SC. Upregulation of CD39/NTPDases and P2 receptors in human pancreatic disease. American journal of physiology Gastrointestinal and liver physiology. 2007; 292:G223-230.

22. Nylund G, Hultman L, Nordgren S and Delbro DS. P2Y2and $\mathrm{P} 2 \mathrm{Y} 4$ purinergic receptors are over-expressed in human colon cancer. Autonomic and Autacoid Pharmacology. 2007; 27:79-84.

23. Liu H, Liu W, Liu Z, Liu Y, Zhang W, Xu L and Xu J. Prognostic value of purinergic P2X7 receptor expression in patients with hepatocellular carcinoma after curative resection. Tumour biology : the journal of the International Society for Oncodevelopmental Biology and Medicine. 2015; 36:5039-49.

24. The Cancer Genome Atlas (TCGA) [https://tcga-data.nci. nih.gov/tcga].

25. Chen X, Cheung ST, So S, Fan ST, Barry C, Higgins J, Lai K-M, Ji J, Dudoit S, Ng IOL, van de Rijn M, Botstein D and Brown PO. Gene Expression Patterns in Human Liver Cancers. Molecular Biology of the Cell. 2002; 13:19291939.

26. Mas VR, Maluf DG, Archer KJ, Yanek K, Kong X, Kulik L, Freise CE, Olthoff KM, Ghobrial RM, McIver P and Fisher R. Genes Involved in Viral Carcinogenesis and Tumor Initiation in Hepatitis C Virus-Induced Hepatocellular Carcinoma. Molecular Medicine. 2009; 15:85-94.

27. Roessler S, Jia H-L, Budhu A, Forgues M, Ye Q-H, Lee J-S, Thorgeirsson SS, Sun Z, Tang Z-Y, Qin L-X and Wang XW. A Unique Metastasis Gene Signature Enables Prediction of Tumor Relapse in Early Stage Hepatocellular Carcinoma Patients. Cancer Research. 2010; 70:1020210212.

28. Wurmbach E, Chen Y-b, Khitrov G, Zhang W, Roayaie S, Schwartz M, Fiel I, Thung S, Mazzaferro V, Bruix J, Bottinger E, Friedman S, Waxman S and Llovet JM. Genome-wide molecular profiles of $\mathrm{HCV}$-induced dysplasia and hepatocellular carcinoma. Hepatology. 2007; 45:938- 
947.

29. Guichard C, Amaddeo G, Imbeaud S, Ladeiro Y, Pelletier L, Maad IB, Calderaro J, Bioulac-Sage P, Letexier M, Degos F, Clement B, Balabaud C, Chevet E, Laurent A, Couchy G, Letouze E, et al. Integrated analysis of somatic mutations and focal copy-number changes identifies key genes and pathways in hepatocellular carcinoma. Nature genetics. 2012; 44:694-698.

30. Rhodes DR, Kalyana-Sundaram S, Mahavisno V, Varambally R, Yu J, Briggs BB, Barrette TR, Anstet MJ, Kincead-Beal C, Kulkarni P, Varambally S, Ghosh D and Chinnaiyan AM. Oncomine 3.0: Genes, Pathways, and Networks in a Collection of 18,000 Cancer Gene Expression Profiles. Neoplasia (New York, NY). 2007; 9:166-180.

31. Kim SM, Leem SH, Chu IS, Park YY, Kim SC, Kim SB, Park ES, Lim JY, Heo J, Kim YJ, Kim DG, Kaseb A, Park YN, Wang XW, Thorgeirsson SS and Lee JS. Sixty-five gene-based risk score classifier predicts overall survival in hepatocellular carcinoma. Hepatology. 2012; 55:1443-1452.

32. Bianchi BR, Lynch KJ, Touma E, Niforatos W, Burgard EC, Alexander KM, Park HS, Yu H, Metzger R, Kowaluk E, Jarvis MF and van Biesen T. Pharmacological characterization of recombinant human and rat $\mathrm{P} 2 \mathrm{X}$ receptor subtypes. European Journal of Pharmacology. 1999; 376:127-138.

33. Burnstock G. Purine-mediated signalling in pain and visceral perception. Trends in Pharmacological Sciences. 2001; 22:182-188.

34. Garcia-Guzman M, Stühmer W and Soto F. Molecular characterization and pharmacological properties of the human P2X3 purinoceptor. Molecular Brain Research. 1997; 47:59-66.

35. Manzoor S, Idrees M, Ashraf J, Mehmood A, Butt S, Fatima K, Akbar H, Rehaman I and Qadri I. Identification of ionotrophic purinergic receptors in Huh-7 cells and their response towards structural proteins of $\mathrm{HCV}$ genotype $3 \mathrm{a}$. Virology Journal. 2011; 8:431.

36. Goree J, Lavoie E, Fausther M and Dranoff J. Expression of mediators of purinergic signaling in human liver cell lines. Purinergic Signalling. 2014; 10:631-638.

37. Espada S, Ortega F, Molina-Jijon E, Rojo AI, Perez-Sen R, Pedraza-Chaverri J, Miras-Portugal MT and Cuadrado A. The purinergic P2Y(13) receptor activates the Nrf2/HO-1 axis and protects against oxidative stress-induced neuronal death. Free radical biology \& medicine. 2010; 49:416-426.

38. Sasaki Y. Does oxidative stress participate in the development of hepatocellular carcinoma? Journal of gastroenterology. 2006; 41:1135-1148.

39. Suzuki Y, Imai K, Takai K, Hanai T, Hayashi H, Naiki T, Nishigaki Y, Tomita E, Shimizu M and Moriwaki H. Hepatocellular carcinoma patients with increased oxidative stress levels are prone to recurrence after curative treatment: a prospective case series study using the d-ROM test. Journal of cancer research and clinical oncology. 2013;
139:845-852.

40. Cockayne DA, Dunn PM, Zhong Y, Rong W, Hamilton SG, Knight GE, Ruan H-Z, Ma B, Yip P, Nunn P, McMahon SB, Burnstock G and Ford APDW. P2X2 knockout mice and $\mathrm{P} 2 \mathrm{X} 2 / \mathrm{P} 2 \mathrm{X} 3$ double knockout mice reveal a role for the $\mathrm{P} 2 \mathrm{X} 2$ receptor subunit in mediating multiple sensory effects of ATP. The Journal of Physiology. 2005; 567:621-639.

41. Hui L, Zatloukal K, Scheuch H, Stepniak E and Wagner EF. Proliferation of human HCC cells and chemically induced mouse liver cancers requires JNK1-dependent p21 downregulation. The Journal of Clinical Investigation. 2008; 118:3943-3953.

42. Chang Q, Chen J, Beezhold K, Castranova V, Shi X and Chen F. JNK1 activation predicts the prognostic outcome of the human hepatocellular carcinoma. Molecular Cancer. 2009; 8:64.

43. Huang B, Li H, Huang L, Luo C and Zhang Y. Clinical significance of microRNA 138 and cyclin D3 in hepatocellular carcinoma. Journal of Surgical Research. 2015; 193:718-723.

44. Wang W, Zhao L-J, Tan Y-X, Ren H and Qi Z-T. MiR138 induces cell cycle arrest by targeting cyclin D3 in hepatocellular carcinoma. Carcinogenesis. 2012; 33:11131120.

45. Lu J-W, Lin Y-M, Chang J-G, Yeh K-T, Chen R-M, Tsai JP, Su W-W and Hu R-M. Clinical implications of deregulated CDK4 and Cyclin D1 expression in patients with human hepatocellular carcinoma. Med Oncol. 2013; 30:1-10.

46. Ledda-Columbano GM, Pibiri M, Concas D, Cossu C, Tripodi $\mathrm{M}$ and Columbano A. Loss of cyclin D1 does not inhibit the proliferative response of mouse liver to mitogenic stimuli. Hepatology. 2002; 36:1098-1105.

47. Fausther M, Gonzales E and Dranoff JA. Role of purinergic $\mathrm{P} 2 \mathrm{X}$ receptors in the control of liver homeostasis. Wiley interdisciplinary reviews Membrane transport and signaling. 2012; 1:341-348.

48. Emmett DS, Feranchak A, Kilic G, Puljak L, Miller B, Dolovcak S, McWilliams R, Doctor RB and Fitz JG. Characterization of ionotrophic purinergic receptors in hepatocytes. Hepatology. 2008; 47:698-705.

49. Doctor RB, Matzakos T, McWilliams R, Johnson S, Feranchak AP and Fitz JG. Purinergic regulation of cholangiocyte secretion: identification of a novel role for P2X receptors. American Journal of Physiology - Gastrointestinal and Liver Physiology. 2005; 288:G779-G786.

50. Graubardt N, Fahrner R, Trochsler M, Keogh A, Breu K, Furer C, Stroka D, Robson SC, Slack E, Candinas D and Beldi G. Promotion of liver regeneration by natural killer cells in a murine model is dependent on extracellular adenosine triphosphate phosphohydrolysis. Hepatology. 2013; 57:1969-1979.

51. Besnard A, Julien B, Gonzales E and Tordjmann T. Innate 
immunity, purinergic system, and liver regeneration: A trip in complexity. Hepatology. 2013; 57:1688-1690.

52. Wu Y, Kuang D-M, Pan W-D, Wan Y-L, Lao X-M, Wang D, Li X-F and Zheng L. Monocyte/macrophage-elicited natural killer cell dysfunction in hepatocellular carcinoma is mediated by CD48/2B4 interactions. Hepatology. 2013; 57:1107-1116.

53. Sun C, Sun H-y, Xiao W-h, Zhang C and Tian Z-g. Natural killer cell dysfunction in hepatocellular carcinoma and NK cell-based immunotherapy. Acta Pharmacol Sin. 2015. 